\title{
THE CLIMATIC PATTERNING OF SPHAGNUM SECT. SPHAGNUM SPECIES DISTRIBUTION IN THE EAST EUROPEAN PLAIN
}

\section{КЛИМАТ КАК ФАКТОР ОПРЕДЕЛЕНИЯ АРЕАЛОВ ВИДОВ SРНАGNUМ SECT. SPHAGNUM НА ВОСТОЧНО-ЕВРОПЕЙСКОЙ РАВНИНЕ}

\author{
SERGEY YU. POPOV ${ }^{1}$ \\ СЕРГЕЙ Ю. ПОПОВ ${ }^{1}$
}

\begin{abstract}
The purpose of this research is to correlate distribution of Sphagnum species with local climatic factors in the East European Plain. Six species of Sphagnum from section Sphagnum, i.e., S. magellanicum, S. centrale, S. palustre, S. papillosum, S. austinii, and S. affine were selected. The graded data on their abundance and the species number for 138 localities were mapped into unit squares of $10 \times 10 \mathrm{~km}$ by using GRID coverage, to construct several delineated zones of occurence/ abundance. For analysis, the matrix was augmented by extended data from the BIOCLIM database. Regression analysis revealed strong correlation between species distribution and temperature, while abundance of the species showed high correlation with maximum relative humidity in two months, August and September, being especially high for most common species, S. magellanicum $(0.85$ and 0.83 ) and $S$. centrale ( 0.81 и 0.76$)$. Distribution area of Sphagnum palustre is restricted by precipitation in the whole warm part of the year, while Sphagnum papillosum avoids regions with low relative humidity in early summer. The local number of species correlates with relative humidity in summer. The developed technique demonstrates a possible way of applying the climatic data to the analysis of the bryophyte distribution in extensive territories.
\end{abstract}

Резюме

Изучается значимость климатических факторов на распространение шести видов Sphagnum секции Sphagnum: S.magellanicum, S. centrale, S. palustre, S .papillosum, S.austinii, S.affine на территории Восточно-Европейской равнины. Корреляционный и регрессионный анализы выявили значимую зависимость между влажностью воздуха и месячных осадков, с одной стороны, и встречаемостью видов и видовым разнообразием секции Sphagnum, с другой. Построены карты распространения видов, отражающие их обилие, а также число видов секции Sphagnum. Они иллюстрируют более высокую встречаемость как отдельных видов, так и их общего числа на северо-западе и западе данной территории, где в летний и осеннее-летний период влажность воздуха выше и осадков больше, чем в остальной части региона. Особенно высоки коэффициенты корреляции между встречаемостью и суммой осадков августа и сентября у двух видов - $S$. centrale ( 0.81 и 0.76 соответственно) u S. magellanicum ( 0.85 и 0.83). Распространение S. papillosum сдерживает продолжительный засушливый период весны и начала лета. В распространении $S$. palustre ведущую роль играет количество осадков всего теплого периода. Для местного разнообразия видов определяющими факторами являются осадки и относительная влажность воздуха в летние месяцы.

KEYWORDS: biogeography, ecology, ARCGIS, BIOCLIM

\section{INTRODUCTION}

Sphagnum mosses are hygrophytes, so their distribution is associated primarily with wetland habitats, such as bogs and mires (Mazing et al., 1990), although in boreal forests they may dominate in the moss carpet as well. On the local scale, Sphagna distribution depends largely on soil moisture and nutrient conditions (Vitt et al., 1975; Chee \& Vitt, 1989; Gignac et al., 1991; Wojutin et al.,
2013). On the global scale, however, the distribution patterns of Sphagnum correlate mainly with the climatic parameters (Gignac \& Vitt, 1990; Gignac at al., 1991; Ignatov, 1993; Melosik, 2006).

Sphagnum bodies are mostly composed of empty hyaline cells, and they may accumulate moisture in tens to hundreds times of their dry weight. The growth of Sphagna starts in spring and continues till autumn, although

\footnotetext{
1 - Lomonosov Moscow State University, Faculty of Biology, Geobotany Dept., Leninskie Gory Str. 1-12, Moscow 119234 Russia - Россия, 119234, Москва, Ленинские Горы, д. 1 стр. 12, Московский государственный университет, биологический факультет; e-mail: s_yu_popov@rambler.ru
} 


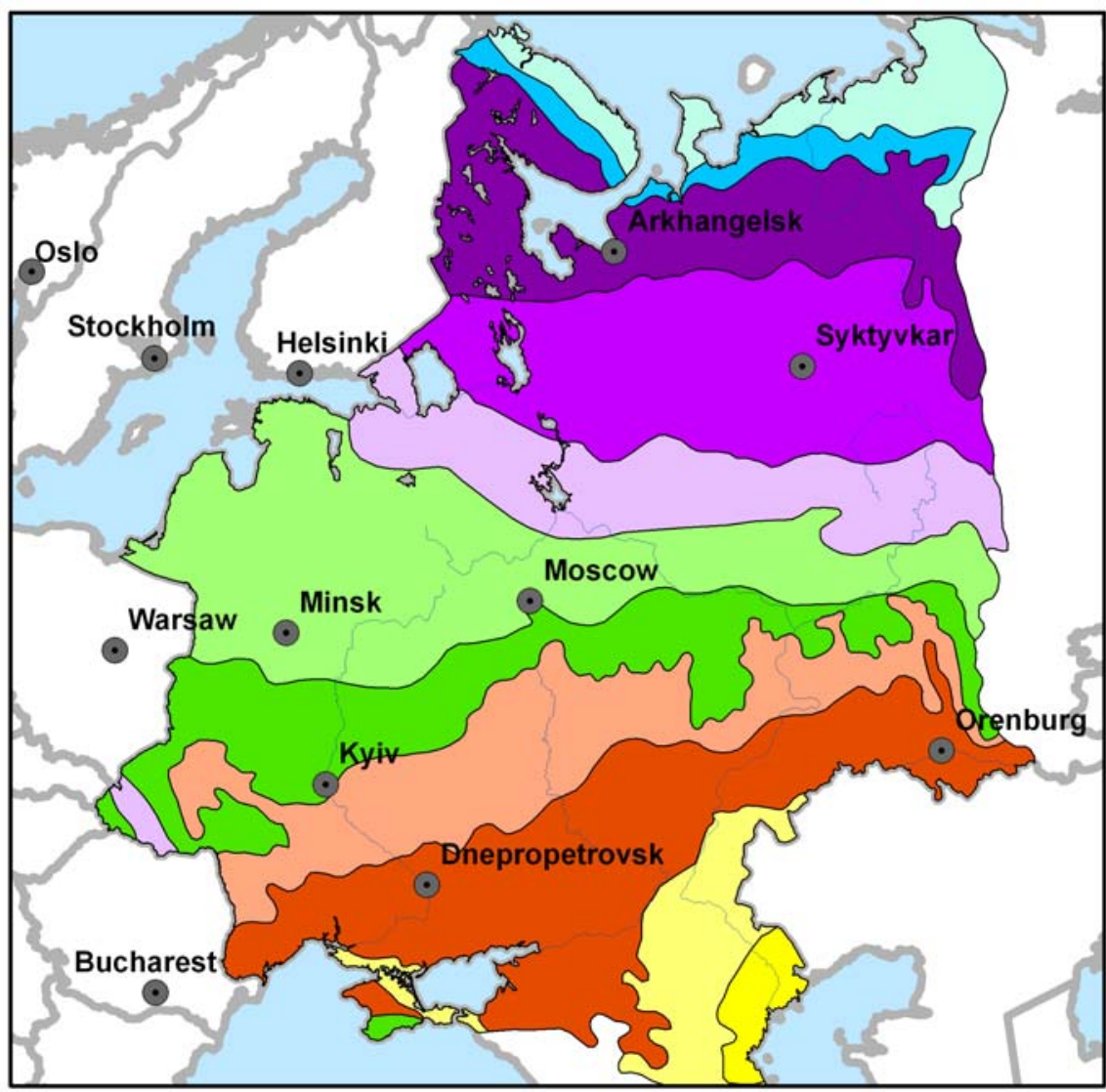

Vegetation zones

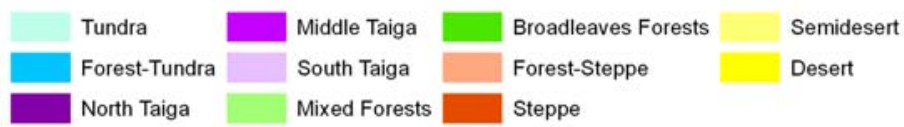

Fig. 1. The East European Plain, taken in the present work, and vegetation zones by Kurnaev (1973) in a dry summer period their growth stops. The growth declines in October, interrupts by cold weather and snow (Savich-Lyubitskaya, 1952; Maksimov, 1982; Grabovik \& Antipin, 1982; Grabovik, 1994). According to Grabovik (1994; 2003) and Grabovik \& Antipin (2015), the intensity of Sphagnum growth in Karelia is strongly dependent on the annual rainfall: in wet years, Sphagnum's annual increment was significant, while in dry years it was very low. Luken (1985) found a similar correlation in Alaska: in the areas with the same temperature, annual increment had a positive correlation with the highest rainfall. Being grown in artificial conditions at $100 \%$ humidity and room temperature, Sphagnum growth was maximum (Clymo, 1965; Smolyanitsky, 1977; Popov, 2012). The latter facts point at the importance of the air humidity just above the ground for Sphagnum growth.

Data on the environmental parameters patterning the distribution of Sphagnum species are rather general. Species diversity is higher in humid areas (Daniels \& Eddy, 1990; Mazing et al., 1990; Ignatov, 1993), while xeric areas have no or almost no species of the genus. Particular studies were conducted to identify an impact of climatic factors on the distribution of Sphagnum mosses, but they were done for limited areas (Gignac \& Vitt, 1990;
Vitt, 1990; Gignac at al., 1991; Melosik, 2006). These works are of considerable interest, because they are based on the statistical analysis of data of meteorological stations and focus on trends in species distribution in a certain type of climate (oceanic, subcontinental, etc.).

The East European Plain (EEP) represents a convenient territory for the study of Sphanum species distribution. Being ca. $2000 \times 2000 \mathrm{~km}$, it has enough contrasting gradients of climatic conditions, from suboceanic to rather continental, and from north boreal types of vegetation to the broad-leaved zone and then to the steppes and semideserts. Distribution of Sphagnum species within the EEP was studied by Kudryashov $(1940 ; 1945)$. He delimited several zones, including those where Sphagna have continuous distribution, zones of dominance of eutrophic species from the section Subsecunda, which are located to the North and South of the forest zone. The present study has the same aim; however, it expands the usage of data on spatial distribution of the climatic parameters.

\section{MATERIAL AND METHODS}

The study area is shown in Figs. 1-2. It roughly corresponds to the East European Plain, somewhat overlapping to neighboring areas. Eleven vegetation zones are represented in its territory according to Kurnaev (1973). 


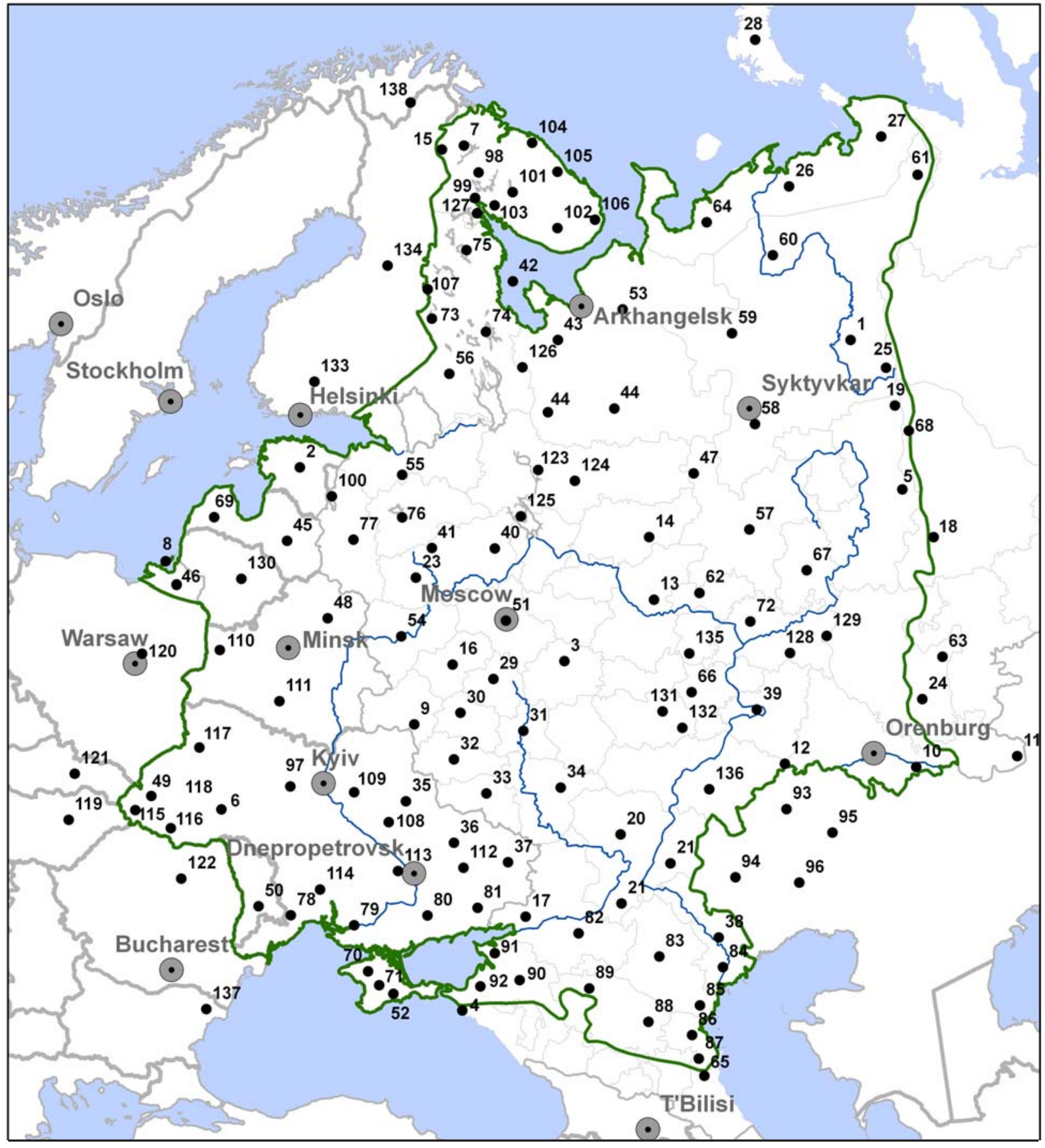

Fig. 2. The local bryofloras used in the analysis of species distribution in the territory approximately corresponding to the East European Plain: 1 - Zheleznova, 1994; Shubina \& Zheleznova, 1995; 2 - Ingerpuu \& Vellak, 1995; 3 - Volosnova et al., 2000; 4 - Ignatova et al., 2005; 5 - Ignatova et al., 1995; 6 - Boljukh, 1995; 7 - Likhachev \& Belkina, 1999; 8 - Dolnik \& Napreenko, 2007; 9 - Anishchenko, 2007; Popova, 2002; 10-12 - Spirina \& Zolotov, 2004; 13 - Popov et al., $2004 ; 14$ Fedosov \& Popov, 2004; 15 - Belkina \& Likhachev, 2004; 16 - Teleganova, 2008; 17 - Sereda \& Ignatov, $2008 ; 18$ Dyachenko et al., 1996; Bezgodov, 2002; 19 - Ignatova et al., 1996; 20-22 - Suragina, 2001; 23 - Ignatov et al., $1998 ; 24$ Zolotov \& Baisheva, 2003; 25 - Zheleznova \& Shubina, 1997; 26-28, 138 - Afonina \& Czernyadjeva, 1995; 29 - Popova, 2002; Volkova, 2006; 30-37 - Popova, 1999, 2002; 38 - Suragina et al., 2002; 39 - Popov, 2002; 40-41 - Notov et al., 2002; 42-44 - Churakova, 2002; 45, 69 - Abolin, 1968; Strazdina, 2012; 46 - Napreenko \& Razgulyaeva, 1999; 47, 57 - Zheleznova, 2014; 48, 110, 111 - Pidoplichko, 1948; Rykovski \& Maslovski, 2009; 49, 115, 116, 118 - Zerov, 1964; Zerov \& Partyka, 1975; 50, 78 - Simonov, 1978; 51 - Ignatov \& Ignatova, 1994; Ignatov et al., 2011; 52, 70, 71 - Partyka, 2005; 53 - Ignatov et al., 1998; Popov \& Buryanina, 2012; 54 - Ignatov \& Ignatova, 2003; 55, 76, 77 - Boch \& Kuzmina, 1985; 56 - Elina et al., 1984; 58-61 - Zheleznova, 1994; 62 - Chernyadjeva, 2001; Chernyadjeva et al., 2013; 63 - Baisheva et al., $2015 ; 64$ Zheleznova \& Shubina, 2015; 65 - Abakarova et al., 2105; 66 - Blagoveschenskii \& Blagoveschenskaya, 1982; 67 - Rubtsova, 
Table 1. Variables from the database BIOCLIM used in analyses bor points. Details of its implementation in ARCGIS is

Codes Explanation

tm 01-12 Mean monthly temperature, ${ }^{\circ} \mathrm{C}$ (for each month)

pr 01-12 Monthly precipitation, mm (for each month)

reh 01-12 Relative humidity, \% (for each month)

pr_a Annual precipitation, $\mathrm{mm}$

amt Annual Mean Temperature

pr_wtm Precipitation of Wettest Month

pr_drm Precipitation of Driest Month

pr_wtq Precipitation of Wettest Quarter

pr_drq Precipitation of Driest Quarter

pr_wmq Precipitation of Warmest Quarter

pr_clq Precipitation of Coldest Quarter

t_wtq Mean Temperature of Wettest Quarter

t_drq Mean Temperature of Driest Quarter

t_wmq Mean Temperature of Warmest Quarter

t_clq Mean Temperature of Coldest Quarter

Bryophytes have been actively studied in this territory in recent decades, accumulating a sufficiently dense coverage of local floras. The main data for the foregoing analysis were obtained from the annotated lists of mosses. These lists commonly evaluate species abundance in the area. Altogether, data from 138 localities were collected, including some with zero values for all species (i.e. lacking all species of Sphagnum sect Sphagnum). Localities were selected so that to be most evenly spread within this territory and overlap slightly beyond the boundaries of the study area to minimize errors from the boundary effects (Fig. 2). For each locality, the abundance of every selected species was ranked by the following scale:

0 - absent;

1 - very rare (1-2 records).

2 - rare (3-7 records).

3 - sporadic (more than 7 records).

4 - frequent, but not always present in suitable habitats.

5 - common and always present in suitable habitats.

These estimates of species abundance were used for composing GRID-covers with the resolution of $10 \mathrm{~km}$ in one pixel. GRID-covers are continuous surfaces. They are based on points with three coordinates $\mathrm{X}, \mathrm{Y}$ and $\mathrm{Z}$ (where $\mathrm{X}$ and $\mathrm{Y}$ are geographic coordinates, and $\mathrm{Z}$ is the species abundance in the given point). The space between the known points is filled by approximations by the kriging method, which estimates the unknown values in the most optimal way based on a system of spatial regression equations, varying from point to point, i.e. the value of each point is weighted by the distance and the value of neigh- discussed by Lurie (2010) and Popov (2013).

The GRID coverage maps with grade data were obtained for six species: Sphagnum magellanicum, S. centrale, S. palustre, S. papillosum, S. austinii, and S. affine. Afterwards, these coverages were transformed to a relation table with 44370 lines ( number of squares of $10 \times 10 \mathrm{~km}$ ). An original matrix had six columns performing the species frequency in a given $10 \times 10$ sq. km, obtained from interpolation by the kriging approximation. An additional seventh column showed a number of species (out of six) in each of the $10 \times 10 \mathrm{~km}$ square. Finally, this matrix was augmented with the climatic data.

Climatic variables selected for the explanation of the species distribution patterns are listed in Table 1. We chose climatic variables that are recommended for the living being distribution analysis in the program BIOCLIM (2009, http://www.andra.fr/bioclim, accessed as of 15 February 2016). In total, the present analysis includes 48 climate variables (Tabl. 1) calculated by this program from the global network of meteorological stations and averaged over the years 1950-2000 (Hijmans et al., 2005).

For each of 48 variables we also built a GRID coverage with a resolution of $10 \mathrm{~km}$ in one pixel (the pixel pitch in DB BIOCLIM is $10^{\prime}$ along the arc of the WGS 84 ellipsoid, which is approximately equal to $10 \mathrm{~km}$ in the projected form). Each GRID coverage was composed in Azimuthal Equidistant Projection (Central Meridian $45^{\circ} \mathrm{E}$, chief of the parallel $-55^{\circ} \mathrm{N}$ ).

Further, the matrix was used for the regression analysis. Climatic parameters (cf. Table 1) were accepted as the predictors, while the abundance of each species expressed as a continuous numeric scale was the response. The method of polynomial multiple regression was used, as a nonlinear dependence was detected between the values of the predictors and the values of response, as well as because of nonnormal distribution of climatic variables . All operations on spatial objects were performed in packages ARCGIS and ERDAS, correlation and regression analysis were done in STATISTICA 6.0.

The final analyzed matrix includes 44370 lines (number of $10 \times 10 \mathrm{~km}$ squares) and 55 columns. Columns represent 48 variables from the BIOCLIM, abundance of six selected species involved in the analysis, and a number of species (out of six) per a given $10 \times 10 \mathrm{~km}$ square.

The dataset was further developed by delineating zones of abundance for each species. The technique com-

2015; 68 - Dyachenko \& Dyachenko, 2010; 72 - Ignatov et al., 2005; Ariskina, 1978; 73 - Maksimov \& Kuznetsov, 2009; 74, 75 - Abramov \& Volkova, 1998; 79, 80, 112, 113 - Boiko, 2009; 83, 85 - Doroshina, 2011; 97, 117 - Zerov, $1964 ; 98,99$ - Belkina \& Likhachev, 1997, 2010; 100 - Andreeva \& Filipieva, 2005; 101-106 - Shljakov \& Konstantinova, $1982 ; 107$ Boichuk, 2001; 108-109 - Gapon, 1997; 119 - Papp et al., 2009; 120 - Stebel, 2012; Melosik, 2006; 121 - Dite et al., 2007 ; 122 - Erzberger et al. (http: abpa.ektf.hu/uploads/papers/finalpdf/ABPA_2_from73to95.pdf); 123 - Karmazina, $2013 ; \mathbf{1 2 4}$ Filippov \& Boichuk, 2015; 125 - Volkova et al,, 1994; 126 - Boichuk et al., 2002; 127 - Bogdanova, 1981; 128-129 Ariskina, 1978; 131 - Serebrjakova, 2009; 132 - Doroshina-Ukrainskya, 1999; 134 - Popova, 1999; 135 - Popov et al., $2001 ; 81,82,84,86,87,88,89,90,91,92,93,94,95,96,136,137$ - zero data, because of the lack any data in literature for south steppe and semidesert adreas; 130, 133, 134, 138 - Söderström, 1998. 

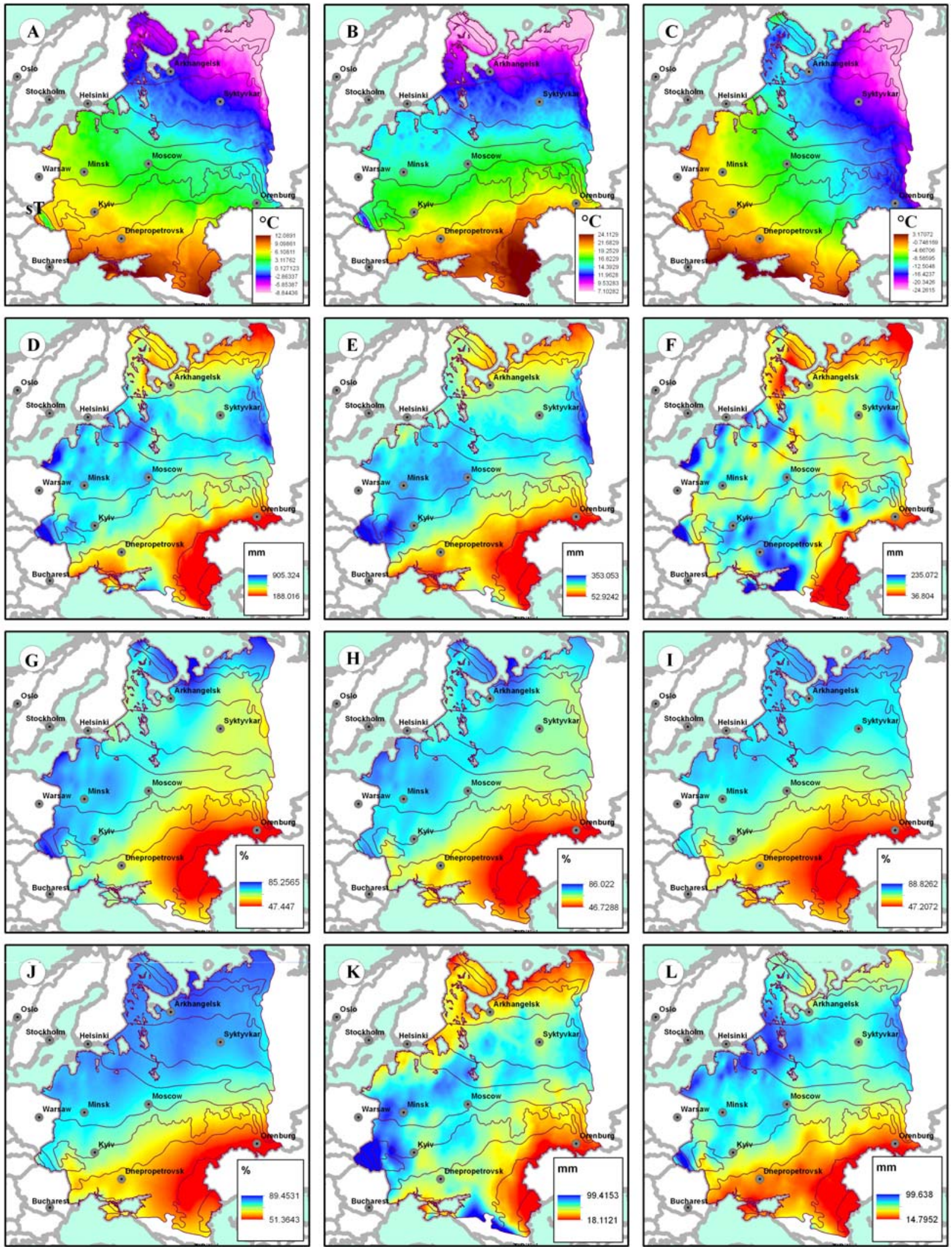

Fig. 3. Distribution of some important climatic variables on the territory of the East European Plain. A - average annual temperature; $\mathrm{B}$ - average temperature of the warmest quarter of the year; $\mathrm{C}$ - average temperature of the coldest quarter; $\mathrm{D}-$ annual precipitation; $\mathrm{E}$ - precipitation of warmest quarter; F - precipitation of coldest quarter; $\mathrm{G}$-relative air humidity of June; $\mathrm{H}$ - relative air humidity of July; I - relative air humidity of August; J - relative air humidity of September; K - precipitation of May; K precipitation of August. Brown lines indicate the boundaries of vegetation zones shown in Fig. 1. 

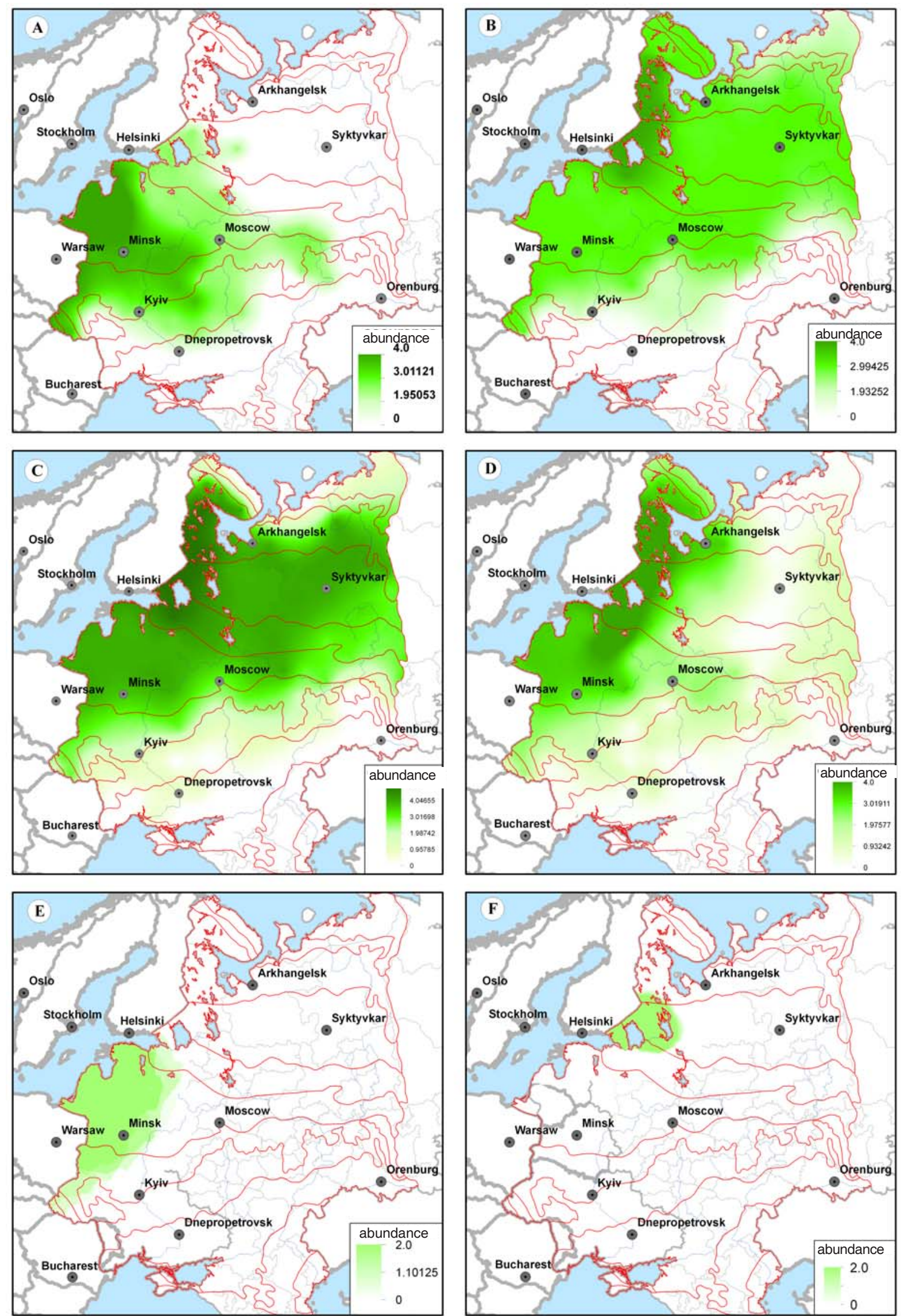

Fig. 4. The model maps of the Sphagnum section Sphagnum species distribution in the East European Plain: A - S. palustre; B - S. centrale; C - S. magellanicum; D - S. papillosum; E - S. austinii; F - S. affine. The limits between zones of abundance (cf. Fig. 5) are given by the kriging method 

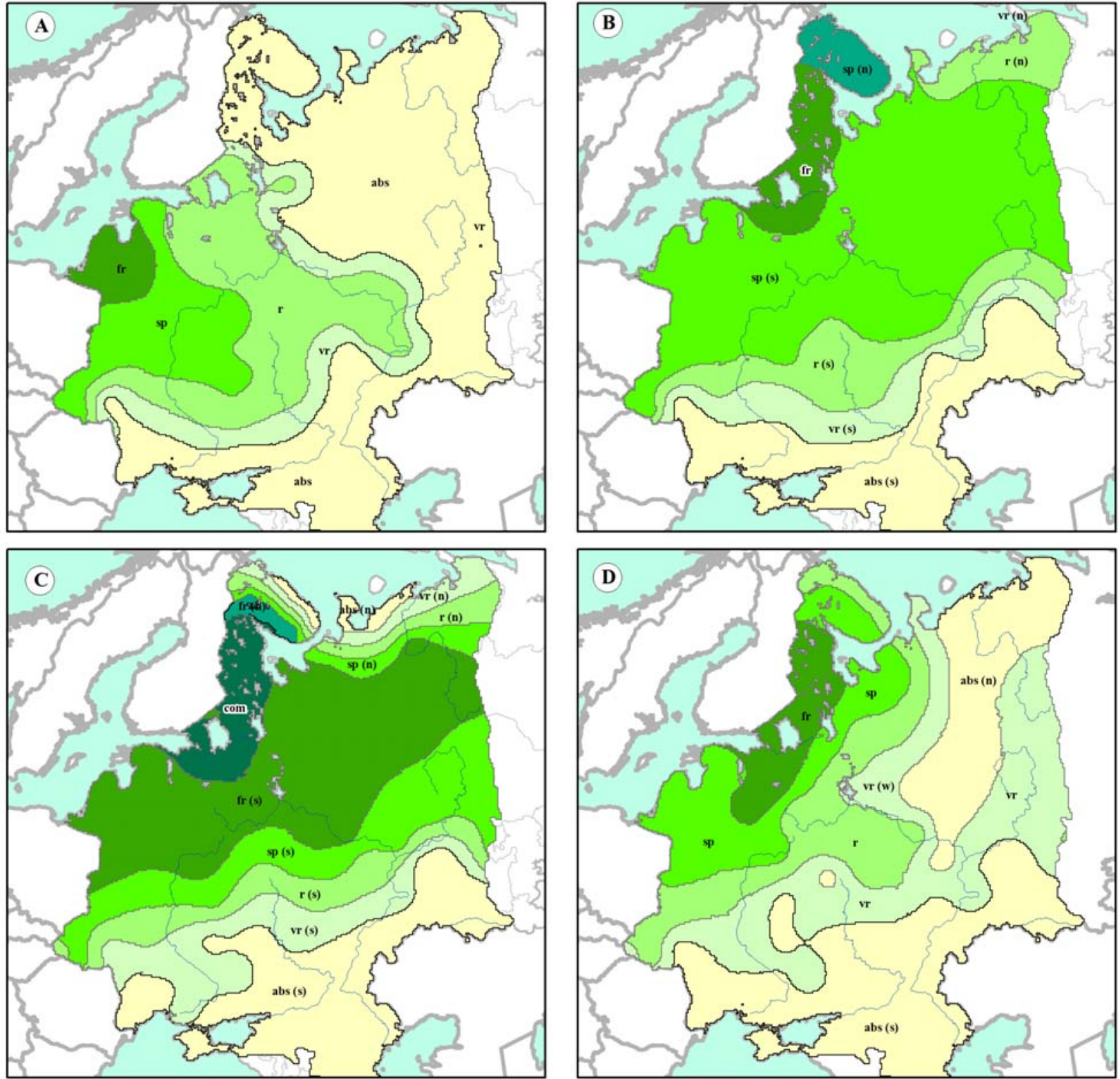

Fig. 5. Zones of abundance of species of Sphagnum sect. Sphagnum in the East European Plain: abs - species is absent; vr very rare; $\mathrm{r}$ - rare; $\mathrm{sp}$ - sporadic; fr - frequently; com - common, or widely distributed; (n) the Northern subzone, (s) - southern subzone. A - S. palustre; B - S. centrale; C - S. magellanicum; D - S. papillosum. The limits between zones of abundance given by the method of "natural breaks" are shown in boxes in Fig. 4.

prised the conversion to the integer coverage by the method of "Natural breaks": the border between the classes was installed in the place where it achieved the best grouping of close values and the maximum difference of values between the classes. Thus the limits between the "integer" values were slightly shifted from continuous values (cf. Fig. 4). The boundaries between the abundance zones of species determined in this way (cf. Fig. 5) were used to calculate the average values of each of 48 climatic variables within every zone of abundance, for each species. The regression analysis of this second matrix was implemented to find the impact of each variable on patterning the distribution of each species.

\section{RESULTS}

Patterns of spatial variation and interrelation of climatic factors in the East European plain

The climate maps of EEP in Fig. 3 illustrate gradual decrease of the temperature to the north and the increase of moisture to the west, towards the Atlantic Ocean. However, the overall patterns are complex, being in a rather good congruence with the general vegetation zonation. Being in general sublatitudinal, the boundaries of the zones bendt first southwesterly and then towards the southeast, delimiting semi-desert and desert territories by a semicircle.

Variation of mean annual temperature is nonlinear. In southern parts of EEP, isotherms are sublatitudinal, in 
its northern parts they bend from northwest to southeast (Fig. 3, A). Winter isotherms are sublongitudinal, (Fig. $3, \mathrm{C}$ ), while summer isotherms have a sublatitudinal direction (Fig. 3). However, the temperature distribution is affected not only by the direct solar radiation, but also by the circulation of air masses and the presence of large water bodies (Alisov, 1956).

There are two atmospheric fronts in the EEP: the Arctic and the Atlantic ones. In summer Atlantic air masses dominate, while in winter winds from the Arctic prevail. Especially noticeable is an increase of precipitation at the Valday Upland and in the Smolensko-Moskovskaya Upland, where the Atlantic air leaves a considerable portion of its humidity (Figs. 3, D, E).

Relative humidity in the north (Arkhangelsk Province) and Northwest (Karelia) is quite high, over $60 \%$, especially in summer (Figs. 3 G-I). In general, relative humidity in the cold time of the year is uneven and in the warm period it increases towards the oceanic regions, so its contours overlap beyond the boundaries of vegetation zones and isotherms of the warm period (Fig. 3, G-J).

Amount of monthly precipitation of the warm period in early summer is highest in the Middle zone of EEP (Fig. 3, K). In late summer, precipitation is maximum in the Northwest (Fig. 3, L).

No correlation has been revealed between mean annual temperature and annual precipitation, precipitation and temperature of summer and winter across localities (Table 2). However, the cross-comparison of (a) monthly relative humidity with (b) monthly rainfall and (c) average monthly temperature reveals an interesting and definite pattern. Among others, a strong positive correlation between monthly rainfall and relative humidity is observed in the late summer to mid-autumn period, i.e., August to October (Table 3). In the same period, there is a strong negative correlation between rainfall and temperature (Table 4). In other words, the higher hydration is achieved in the more northern areas of EEP. However, strong negative correlation between monthly mean temperatures and relative humidity does not change during the whole year (Table 3); this fact indicates that the saturation of air with water vapor is always higher in the north of EEP.

Thus, in the autumn and summer periods relative humidity depends directly on the rainfall and indirectly on the temperature. This rule is especially important in a view of the second peak of active growth of Sphagnum during the vegetation period (Grabovik \& Antipin, 1982).

Patterns of distribution of species of the section Sphagnum on the East European Plain

Six Sphagnum species of the section Sphagnum known in EEP are characterized by rather different distribution patterns (Figs. 4, 5). The role of different climatic variables in their patterning is shown in Table 5. Already simple visual comparison of maps of distribution of moisture factors (Fig. 3G, L) and occurrence of Sphangum species (Fig. 4, 5) reveals that Sphagna are more diverse in more humid areas in the Northwest of European Russia and in the Baltic States. Most important are the high rainfall and relative humidity in autumn and summer. However, the obtained data reveal some more details explaining species patterning.

Contribution of climatic variables to the explanation of species distribution is summarized in Figs. 6-9. Table 6 provides data confirming a high level of explanatory capability of the climatic data.

\section{Sphagnum palustre}

\section{DISCUSSION}

This species occurs in the forest, forest-steppe and steppe zones in the Central and Western regions of EEP (Fig. 4A). It reaches the highest frequency at its western borders (Fig. 5A), however its abundance never exceeds 4 in local floras. Correlation analysis shows that most important factors determining its distribution are the amount of precipitation in summer and the sum of precipitation for months of spring and summer (Table 5). Strong correlation with precipitation is observed already in March and April (Table 5), unlike other species of the section Sphagnum discussed here. Since that time Sphagnum palustre begins its first peak of active growth (Grabovik \& Antipin, 1982), which seems to be most important for this species. Unlike S. magellanicum, $S$. centrale and $S$. papillosum, there is a positive correlation of the abundance of $S$. palustre with temperature characteristics, but it is weak for the summer period and rather strong for winter months (Table 5). This means that $S$. palustre reaches the highest abundance in regions with short, warm winters. Fig. 6 shows that the relative humidity in summer months remains about the same in the area where $S$. palustre occurs, never dropping below $60 \%$.

The comparison of Fig. 3 and $5 \mathrm{~A}$ indicates that the northern boundary of «very rare»zone of $S$. palustre is parallel to the isotherms of winter temperatures, while its southern border depends on summer temperatures and follows isolines of relative humidity in late summer. This means that $S$. palustre is sensitive to the decrease of winter temperatures (and, apparently, related to a reduction in the duration of the winter period) and to the increase of summer temperatures (and the associated decrease in precipitation and humidity), and these factors restrict the distribution of this species. The larger part of its distribution is confined to the areas with maximum relative humidity and precipitation of the warm period (Fig. 3, D, E, $\mathrm{G}, \mathrm{K})$.

Thus, $S$. palustre tends to be common in areas with the suboceanic climate. Gignac \& Vitt (1990) also referred this species as suboceanic, basing on their studies of transect crossing the different types of climate in Western Canada.

The regression analysis shows that the occurrence of $S$. palustre in the EEP is determined by climatic factors at $90.6 \%$ (Table 6). 
Table 2. The Pearson correlation coefficient between indicators of moisture and temperature for different periods of the year (the transcript notation see table. 1) (all values at level $\mathrm{p}<0.05$ ).

$\begin{array}{llllllll} & \text { pr_wtq } & \text { pr_wtm } & \text { pr_wmq } & \text { pr_drq } & \text { pr_drm } & \text { pr_clq } & \text { pr_a } \\ \text { t_wtq } & -0.359535 & -0.289570 & -0.291563 & 0.016944 & -0.033481 & 0.076180 & -0.348773 \\ \text { t_wmq } & -0.388909 & -0.318326 & -0.355634 & 0.096391 & 0.045213 & 0.166367 & -0.353339 \\ \text { t_drq } & -0.230896 & -0.195838 & -0.232799 & 0.310200 & 0.279664 & 0.383091 & -0.154659 \\ \text { t_clq } & 0.020720 & 0.038853 & 0.004990 & 0.362679 & 0.281148 & 0.265806 & -0.010605 \\ \text { amt } & -0.147676 & -0.110268 & -0.141448 & 0.290921 & 0.219295 & 0.257793 & -0.148296\end{array}$

Table 3. The Pearson correlation coefficient between the monthly rainfall, average monthly temperature and average monthly relative humidity (transcript notation see table. 1) (all values at level $\mathrm{p}<0.05$ )

\begin{tabular}{|c|c|c|c|c|c|c|c|c|c|c|c|c|}
\hline 01 & reh01 & reh02 & reh03 & reh04 & reh05 & reh06 & reh07 & reh08 & reh09 & reh10 & reh11 & reh12 \\
\hline $\begin{array}{l}\text { pr01 } \\
\text { pr02 }\end{array}$ & -0.0417 & -0.5141 & & & & & & & & & & \\
\hline pr03 & & & -0.3250 & & & & & & & & & \\
\hline pr04 & & & & 0.0338 & & & & & & & & \\
\hline pr05 & & & & & 0.1886 & & & & & & & \\
\hline pr06 & & & & & & 0.3913 & & & & & & \\
\hline pr07 & & & & & & & 0.4952 & & & & & \\
\hline pr08 & & & & & & & & 0.7379 & & & & \\
\hline pr09 & & & & & & & & & 0.7744 & & & \\
\hline pr10 & & & & & & & & & & 0.7324 & & \\
\hline pr11 & & & & & & & & & & & 0.3021 & \\
\hline pr12 & & & & & & & & & & & & -0.0757 \\
\hline $\operatorname{tm} 01$ & -0.7885 & & & & & & & & & & & \\
\hline $\operatorname{tm} 02$ & & -0.8297 & & & & & & & & & & \\
\hline $\operatorname{tm} 03$ & & & -0.7693 & & & & & & & & & \\
\hline tm04 & & & & -0.7228 & & & & & & & & \\
\hline $\operatorname{tm} 05$ & & & & & -0.6130 & & & & & & & \\
\hline $\operatorname{tm} 06$ & & & & & & -0.6231 & & & & & & \\
\hline $\operatorname{tm} 07$ & & & & & & & -0.8150 & & & & & \\
\hline $\operatorname{tm} 08$ & & & & & & & & -0.9020 & & & & \\
\hline $\operatorname{tm} 09$ & & & & & & & & & -0.8662 & & & \\
\hline $\operatorname{tm} 10$ & & & & & & & & & & -0.7951 & & \\
\hline $\operatorname{tm} 11$ & & & & & & & & & & & -0.8983 & \\
\hline $\operatorname{tm} 12$ & & & & & & & & & & & & -0.8405 \\
\hline
\end{tabular}

Table 4. The Pearson correlation coefficient between the monthly rainfall and average monthly temperature (the transcript notation see table. 1) (all values at level $\mathrm{p}<0.05$ )

\begin{tabular}{|c|c|c|c|c|c|c|c|c|c|c|c|}
\hline pr01 & pr02 & pr03 & pr04 & pr05 & pr06 & pr07 & pr08 & pr09 & pr10 & pr11 & pr12 \\
\hline $\begin{array}{l}\operatorname{tm} 010.1325 \\
\operatorname{tm} 02\end{array}$ & 0.5014 & & & & & & & & & & \\
\hline tm03 & & 0.3768 & & & & & & & & & \\
\hline tm04 & & & 0.1978 & & & & & & & & \\
\hline tm05 & & & & -0.0202 & & & & & & & \\
\hline $\operatorname{tm} 06$ & & & & & -0.0878 & & & & & & \\
\hline tm07 & & & & & & -0.3257 & & & & & \\
\hline $\operatorname{tm} 08$ & & & & & & & -0.6737 & & & & \\
\hline $\operatorname{tm} 09$ & & & & & & & & -0.7627 & & & \\
\hline $\operatorname{tm} 10$ & & & & & & & & & -0.6793 & & \\
\hline $\operatorname{tm} 11$ & & & & & & & & & & -0.1717 & \\
\hline $\operatorname{tm} 12$ & & & & & & & & & & & 0.2513 \\
\hline
\end{tabular}

\section{Sphagnum centrale}

This species occurs in all zones, from tundra to steppe, but its frequency declines both to the south and to the north of the forest zone. Its maximum abundance was found in the Northwestern region of European Russia (Figs. 4, 5). Maximum abundance in local floras reaches 4 according to the adopted scale.

The abundance of $S$. centrale has fairly strong positive correlation with the precipitation and relative humidity in the period from late summer to mid autumn (August-October) and negative correlation with the temper- ature in this period. Thus, its distribution covers the whole forest zone, generally following patterns of precipitation and humidity in EEP (Fig. 3). Negative correlation of its occurrence with summer temperatures results in the increase of its abundance towards the Northwest.

Southern border of the area where $S$. centrale is rare (i.e., zones $\boldsymbol{r}(\boldsymbol{n})$ and $\boldsymbol{r}(\boldsymbol{s})$ in Fig. 5) are parallel to the isotherms of the warm period of the year (Fig. 3B). The area of its maximum frequency more or less coincides with the zone of maximum rainfall in August (Fig. 3L), and in September and October. Thus, the limiting climatic fac- 
Table. 5. The Pearson correlation coefficient between the values of climatic factors and species abundance and number of species (count_sp). Bold highlighted values of $\mathrm{r}>0.5$ in absolute value. The statistically significant values are marked by asterisk $* p<0,05 ; * *<<0,01 ; * * * p<0,001$. All values for Sphagnum affine are non significant at $\mathrm{p}>0.05$.

\begin{tabular}{|c|c|c|c|c|c|c|c|}
\hline & palustre & centrale & magellanicum & papillosum & austinii & affine & count_sp \\
\hline reh04 & $-0.03 * *$ & $\mathbf{0 . 5 8} * * *$ & $0.62 * * *$ & $\mathbf{0 . 5 0} * * *$ & $0.26^{*}$ & 0.05 & $0.39 * * *$ \\
\hline reh05 & $0.04 * * *$ & $0.44 * * *$ & $0.4 * * *$ & $0.44 * * *$ & $0.40 *$ & 0.01 & $0.34 * * *$ \\
\hline reh06 & $0.29 * * *$ & $0.52 * * *$ & $0.51 * * *$ & $0.60 * * *$ & $0.53^{*}$ & 0.04 & $0.54 * * *$ \\
\hline reh07 & $0.29 * * *$ & $0.67 * * *$ & $0.67 * * *$ & $0.71 * * *$ & $0.52 *$ & 0.05 & $0.63 * * *$ \\
\hline reh08 & $-0.02 * * *$ & $0.69 * * *$ & $0.72 * * *$ & $0.57 * * *$ & $0.26^{*}$ & 0.08 & $0.45 * * *$ \\
\hline reh09 & $-0.08 * * *$ & $0.72 * * *$ & $0.74 * * *$ & $0.53 * * *$ & $0.18^{*}$ & 0.08 & $0.42 * * *$ \\
\hline reh10 & $-0.14 * * *$ & $0.70 * * *$ & $0.74 * * *$ & $0.42 * * *$ & $0.05^{*}$ & 0.02 & $0.36 * * *$ \\
\hline pr_wtq & $\mathbf{0 . 5 3} * * *$ & $0.64 * * *$ & $0.66 * * *$ & $0.63 * * *$ & $0.50 *$ & 0.15 & $\mathbf{0 . 7 5} * * *$ \\
\hline pr_wtm & $\mathbf{0 . 5 3} * * *$ & $0.61 * * *$ & $0.60 * * *$ & $\mathbf{0 . 5 8} * * *$ & $0.41 *$ & 0.15 & $\mathbf{0 . 7 2} * * *$ \\
\hline pr_wmq & $\mathbf{0 . 5 3} * * *$ & $0.62 * * *$ & $0.63 * * *$ & $0.60 * * *$ & $0.48 *$ & 0.09 & $0.73 * * *$ \\
\hline pr_drq & $0.49 * * *$ & $0.14 * * *$ & $0.18 * * *$ & $0.27 * * *$ & $0.34 *$ & 0.10 & $0.41 * * *$ \\
\hline pr_drm & $0.44 * * *$ & $0.13 * * *$ & $0.19 * * *$ & $0.25 * * *$ & $0.30 *$ & 0.09 & $0.38 * * *$ \\
\hline pr_clq & $0.40 * * *$ & $0.07 *$ & $0.10 * * *$ & $0.15^{* * *}$ & $0.18 *$ & 0.11 & $0.29 * * *$ \\
\hline pr_a & $0.49 * * *$ & $0.62 * * *$ & $0.66 * * *$ & $0.58 * * *$ & $0.46^{*}$ & 0.15 & $0.69 * * *$ \\
\hline $\operatorname{tm01}$ & $0.44 * * *$ & $-0.31 * * *$ & $-0.33 * * *$ & $0.03 * *$ & $0.40 *$ & 0.05 & $0.09 * * *$ \\
\hline $\operatorname{tm} 02$ & $0.47 * * *$ & $-0.27 * * *$ & $-0.29 * * *$ & $0.04 * *$ & $0.41 *$ & 0.05 & $0.12 * * *$ \\
\hline $\operatorname{tm} 03$ & $0.45 * * *$ & $-0.34 * * *$ & $-0.34 * * *$ & $-0.07 * *$ & $0.36^{*}$ & 0.04 & $0.05 * * *$ \\
\hline $\operatorname{tm} 04$ & $0.29 * * *$ & $-0.60 * * *$ & $-0.61 * * *$ & $-0.32 * *$ & $0.13 *$ & -0.04 & $-0.20 * * *$ \\
\hline $\operatorname{tm} 05$ & $0.22 * * *$ & $-0.66^{* * *}$ & $-0.67 * * *$ & $-0.40 * * *$ & $0.01 *$ & -0.04 & $-0.29 * * *$ \\
\hline $\operatorname{tm} 06$ & $0.16^{* * *}$ & $-0.69 * * *$ & $-\mathbf{0 . 7 0} * * *$ & $-0.46^{* * *}$ & $-0.06^{*}$ & -0.05 & $-0.34 * * *$ \\
\hline $\operatorname{tm} 07$ & $0.06^{* * *}$ & $-0.71 * * *$ & $-0.71 * * *$ & $-0.55 * * *$ & $-0.18^{*}$ & -0.05 & $-0.44 * * *$ \\
\hline $\operatorname{tm} 08$ & $0.20 * * *$ & $-0.67 * * *$ & $-0.67 * * *$ & $-0.42 * * *$ & $0.00 *$ & -0.03 & $-0.30 * * *$ \\
\hline $\operatorname{tm} 09$ & $0.26 * * *$ & $-0.63 * * *$ & $-0.63 * * *$ & $-0.34 * * *$ & $0.12 *$ & -0.02 & $-0.24 * * *$ \\
\hline $\operatorname{tm} 10$ & $0.39 * * *$ & $-0.46^{* * *}$ & $-0.46^{* * *}$ & $-0.13^{* * *}$ & $0.31 *$ & 0.02 & $-0.04 * * *$ \\
\hline $\operatorname{tm} 11$ & $0.42 * * *$ & $-0.38 * * *$ & $-0.39 * * *$ & $-0.05^{*}$ & $0.36^{*}$ & 0.04 & $0.02 * * *$ \\
\hline $\operatorname{tm} 12$ & $0.43 * * *$ & $-0.34 * * *$ & $-0.36 * * *$ & $0.00 * * *$ & $0.37 *$ & 0.05 & $0.06 * * *$ \\
\hline pr01 & $0.27 * * *$ & $-0.01 * * *$ & $0.03 * * *$ & $0.04 * *$ & $0.05^{*}$ & 0.08 & $0.14 * * *$ \\
\hline pr02 & $0.40 * * *$ & $-0.08^{* *}$ & $-0.06 * * *$ & $0.07 * *$ & $0.18^{*}$ & 0.09 & $0.18 * * *$ \\
\hline pr03 & $0.52 * * *$ & $0.25 * * *$ & $0.30 * * *$ & $0.39 * * *$ & $0.48 *$ & 0.16 & $0.48 * * *$ \\
\hline pr04 & $0.54 * * *$ & $0.24 * * *$ & $0.28 * * *$ & $0.36 * * *$ & $0.40 *$ & 0.09 & $\mathbf{0 . 5 0} * * *$ \\
\hline pro5 & $0.45^{* * *}$ & $0.37 * * *$ & $0.39 * * *$ & $0.34 * * *$ & $0.36^{*}$ & -0.03 & $0.50 * * *$ \\
\hline pr06 & $0.53 * * *$ & $0.39 * * *$ & $0.42 * * *$ & $0.45^{* * *}$ & $0.42 *$ & 0.00 & $\mathbf{0 . 5 8} * * *$ \\
\hline pr07 & $0.54 * * *$ & $0.61 * * *$ & $0.60 * * *$ & $0.54 * * *$ & $0.40 *$ & 0.08 & $0.71 * * *$ \\
\hline pros & $0.31 * * *$ & $0.81 * * *$ & $0.85 * * *$ & $0.73 * * *$ & $0.40 *$ & 0.16 & $\mathbf{0 . 7 2} * * *$ \\
\hline pr09 & $0.10 * * *$ & $0.76 * * *$ & $0.83 * * *$ & $0.56^{* * *}$ & $0.25^{*}$ & 0.13 & $0.55 * * *$ \\
\hline pr10 & $0.01 * * *$ & $0.72 * * *$ & $0.76 * * *$ & $0.47 * * *$ & $0.05^{*}$ & 0.14 & $0.42 * * *$ \\
\hline pr11 & $0.34 * * *$ & $0.58 * * *$ & $0.62 * * *$ & $0.50 * * *$ & $0.29 *$ & 0.15 & $0.54 * * * *$ \\
\hline pr12 & $0.43 * * *$ & $0.23 * * *$ & $0.26 * * *$ & $0.25 * * *$ & $0.26^{*}$ & 0.15 & $0.38 * * *$ \\
\hline amt & $0.36 * * *$ & $-0.51 * * *$ & $-0.51 * * *$ & $-0.21 * * *$ & $0.26^{*}$ & 0.00 & $-0.09 * * *$ \\
\hline t_wtq & $0.17 * * *$ & $-0.62 * * *$ & $-0.64 * * *$ & $-0.42 * * *$ & $-0.09 *$ & -0.06 & $-0.29 * * *$ \\
\hline t_wmq & $0.17 * * *$ & $-0.69 * * *$ & $-\mathbf{0 . 7 0} * * *$ & $-0.46 * * *$ & $-0.06^{*}$ & -0.04 & $-0.34 * * *$ \\
\hline t_drq & $0.25 * * *$ & $-0.50 * * *$ & $-0.51 * * *$ & $-0.25 * * *$ & $0.17 *$ & 0.01 & $-0.18 * * *$ \\
\hline t_clq & $0.45^{* * *}$ & $-0.28 * * *$ & $-0.31 * * *$ & $0.04 * * *$ & $0.40 *$ & 0.04 & $0.11 * * *$ \\
\hline
\end{tabular}

Table. 6. Indicators of the quality of the regression analysis

$\begin{array}{lllllll} & \text { Multiple R } & \mathbf{R}^{2} & \text { St. err. } & \text { F } & \text { df } & \text { p-level } \\ \text { S. palustre } & 0.95199461 & 0.90629374 & 0.352617792 & 8863.66 & 48,43990 & 0.000000 \\ \text { S. centrale } & 0.97774316 & 0.95598168 & 0.254552183 & 19903.47 & 48,43990 & 0.000000 \\ \text { S. magellanicum } & 0.97324380 & 0.94720350 & 0.370147647 & 16441.86 & 48,43990 & 0.000000 \\ \text { S. papillosum } & 0.95854016 & 0.91879923 & 0.327381372 & 10369.87 & 48,43990 & 0.000000 \\ \text { S. austinii } & 0.91858434 & 0.84379719 & 0.097454125 & 4950.64 & 48,43990 & 0.000000 \\ \text { S. affine } & 0.69103505 & 0.47752944 & 0.111912753 & 837.62 & 48,43990 & 0.000000 \\ \text { Count_sp } & 0.96623643 & 0.93361283 & 0.349143500 & 12888.29 & 48,43990 & 0.000000\end{array}$



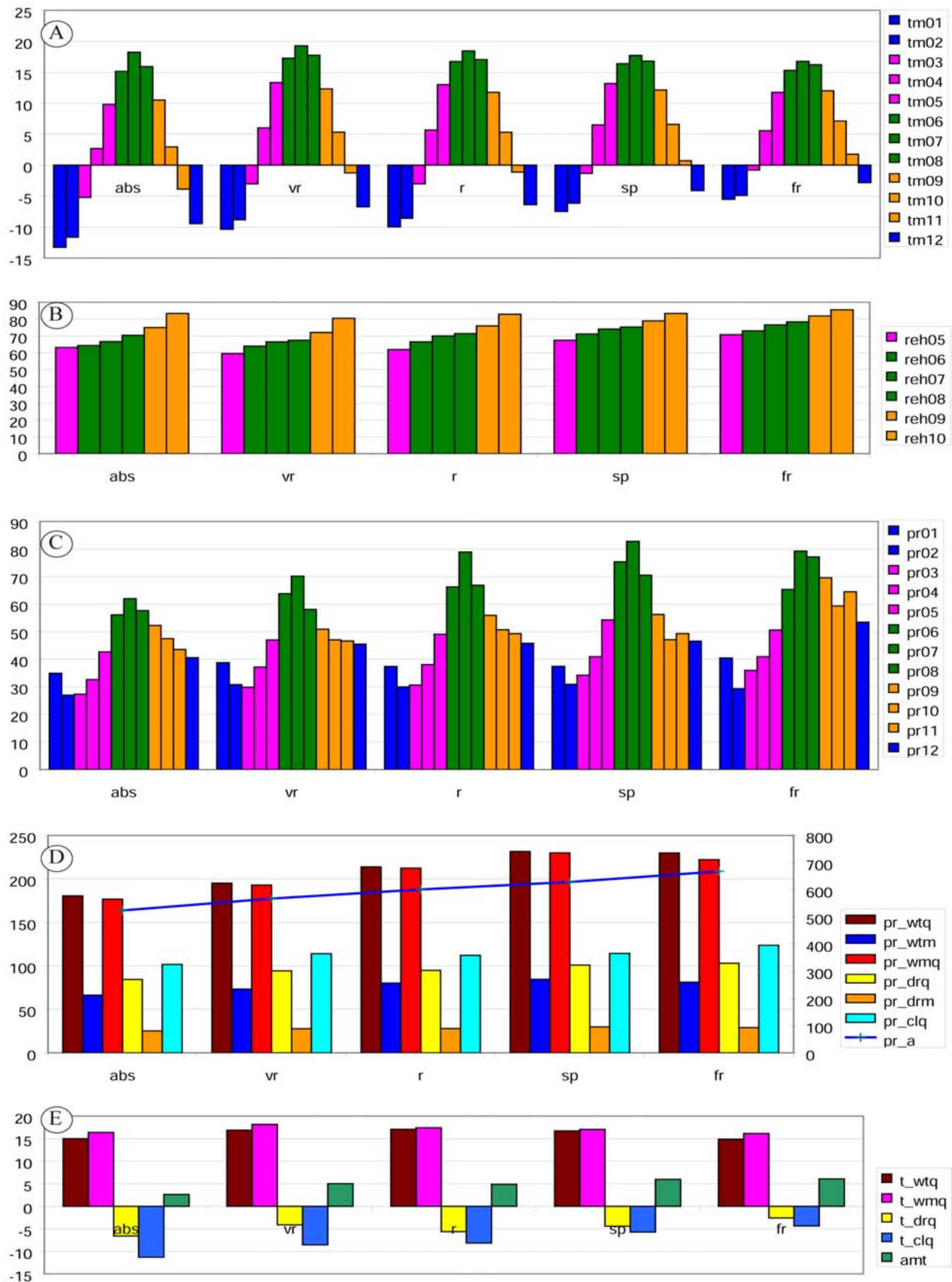

Fig. 6. Absolute values of climatic variables (see Table 1 for abbreviations) for zones of abundance (shown in Fig. 5) of Sphagnum palustre: A - temperature, monthly; B - relative humidity, warm months only; C - precipitation, monthly; D - precipitation (blue line indicates annual precipitation, with scale on the right; bars show precipitation by selected periods, their scales are on the left); $\mathrm{E}$ - temperature of selected periods. 


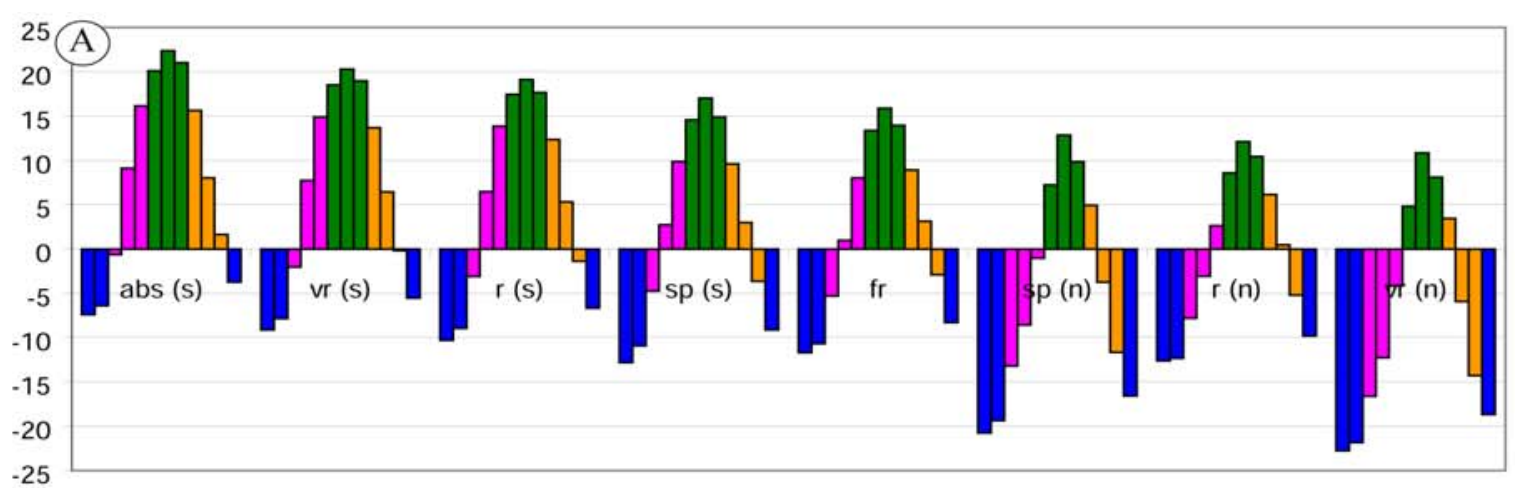

120

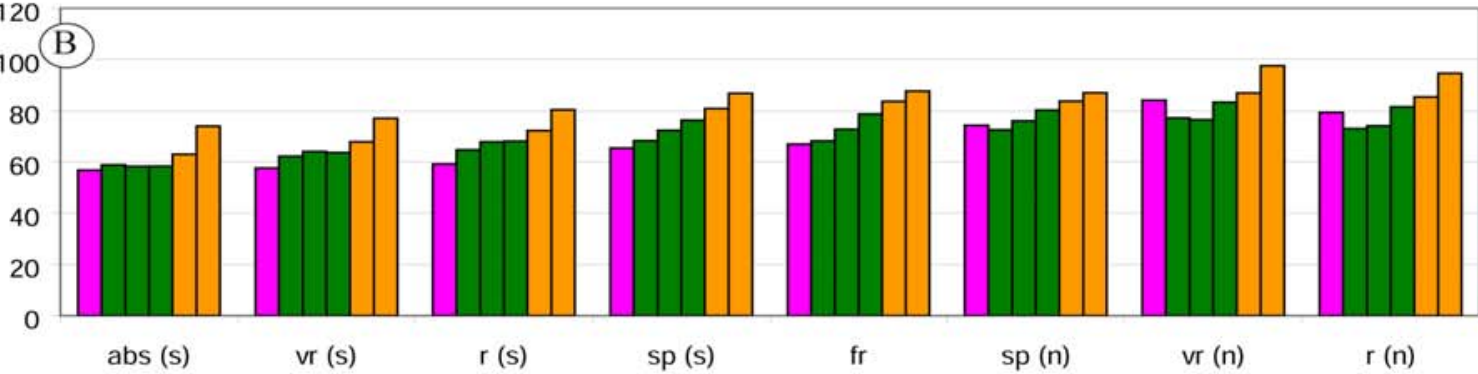
$\mathbf{a t m}_{\mathrm{tm}}$
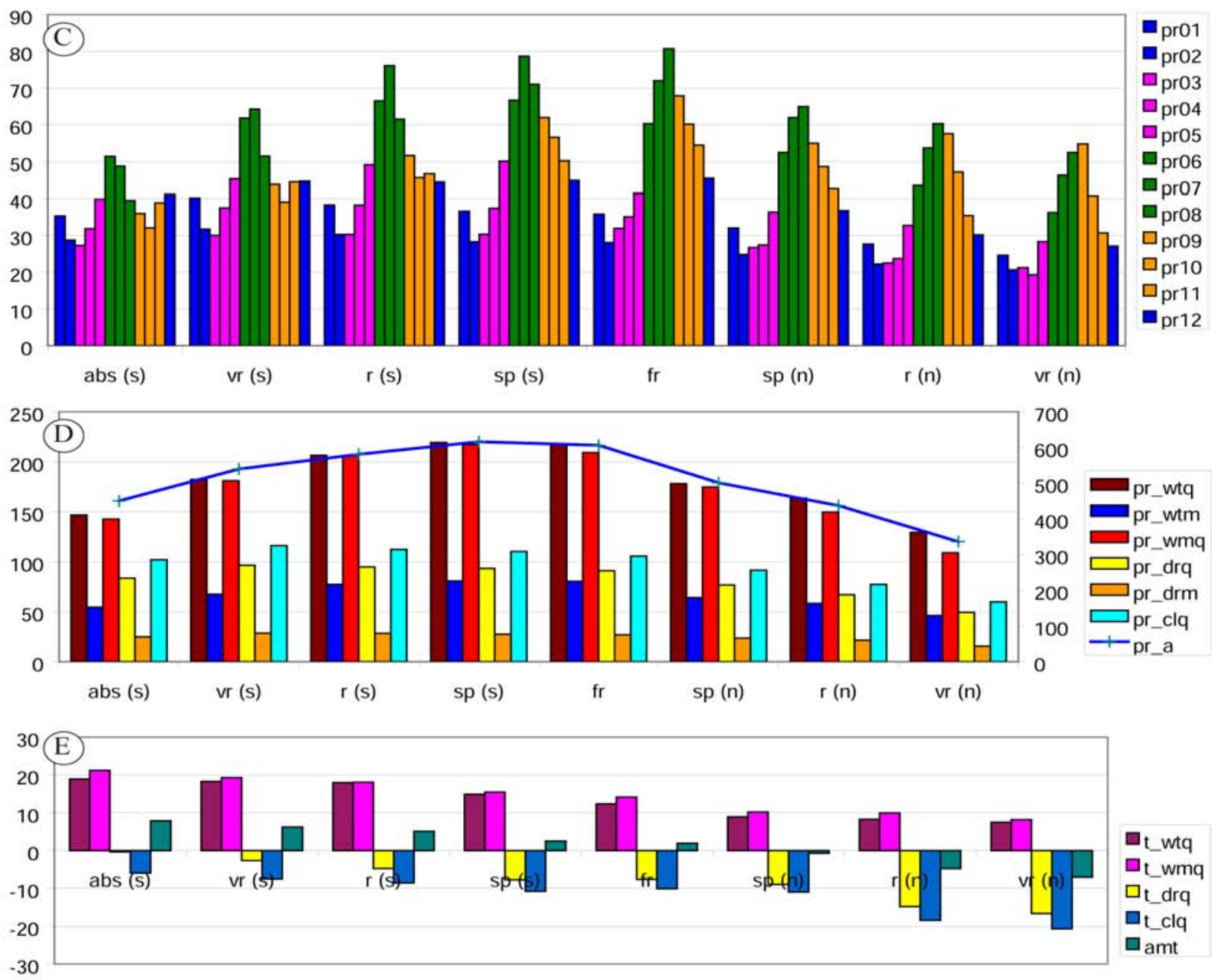

Fig. 7. Absolute values of climatic variables (see Table 1 for abbreviations) for zones of abundance (shown in Fig. 5) of Sphagnum centrale: A - temperature, monthly; B - relative humidity, warm months only; C - precipitation, monthly; D - precipitation (blue line indicates annual precipitation, with scale on the right; bars show precipitation by selected periods, their scales are on the left); E - temperature of selected periods. 

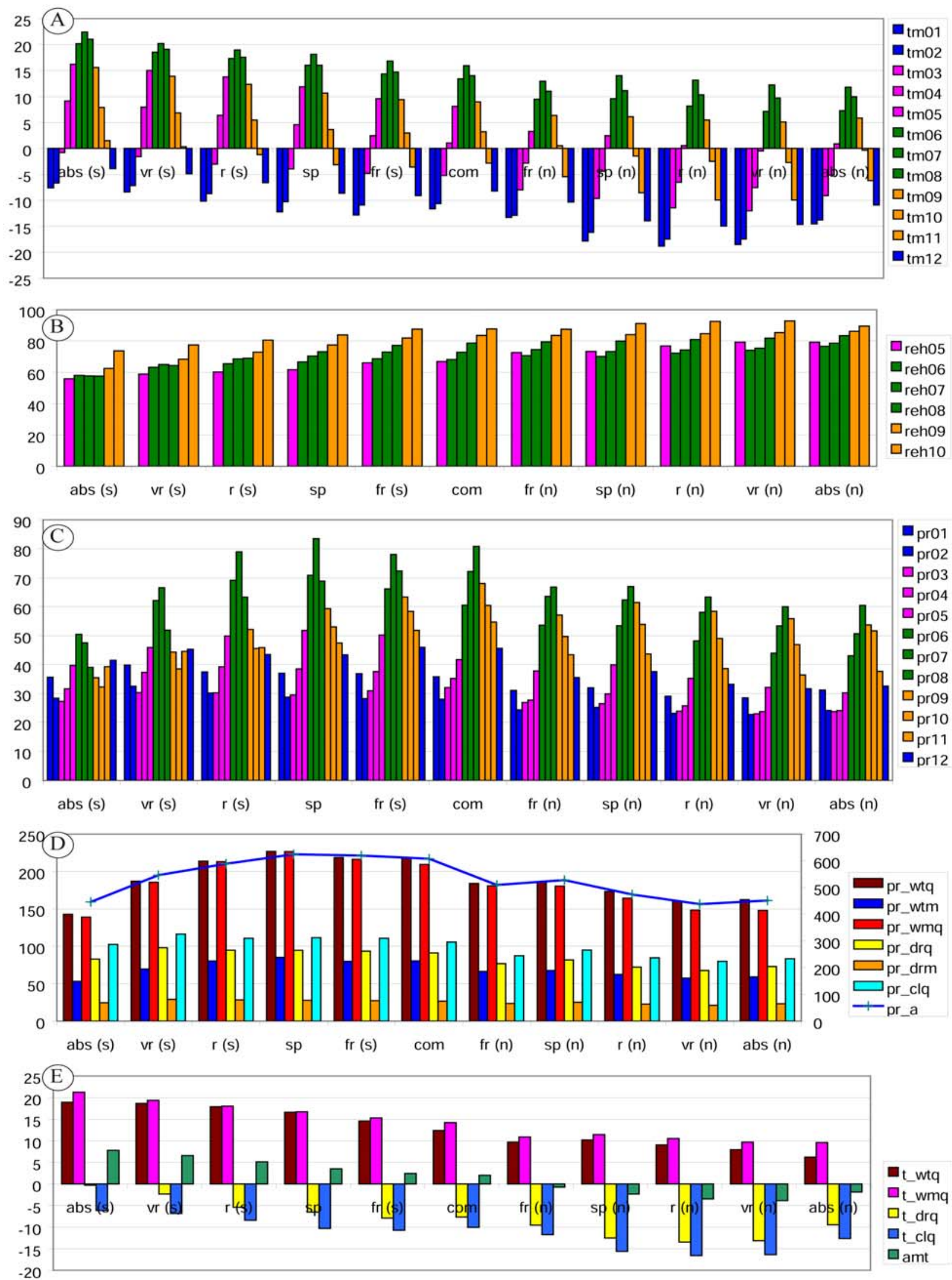

Fig. 8. Absolute values of climatic variables (see Table 1 for abbreviations) for zones of abundance (shown in Fig. 5) of Sphagnum magellanicum: A - temperature, monthly; B - relative humidity, warm months only; C - precipitation, monthly; D precipitation (blue line indicates annual precipitation, with scale on the right; bars show precipitation by selected periods, their scales are on the left); E - temperature of selected periods. 

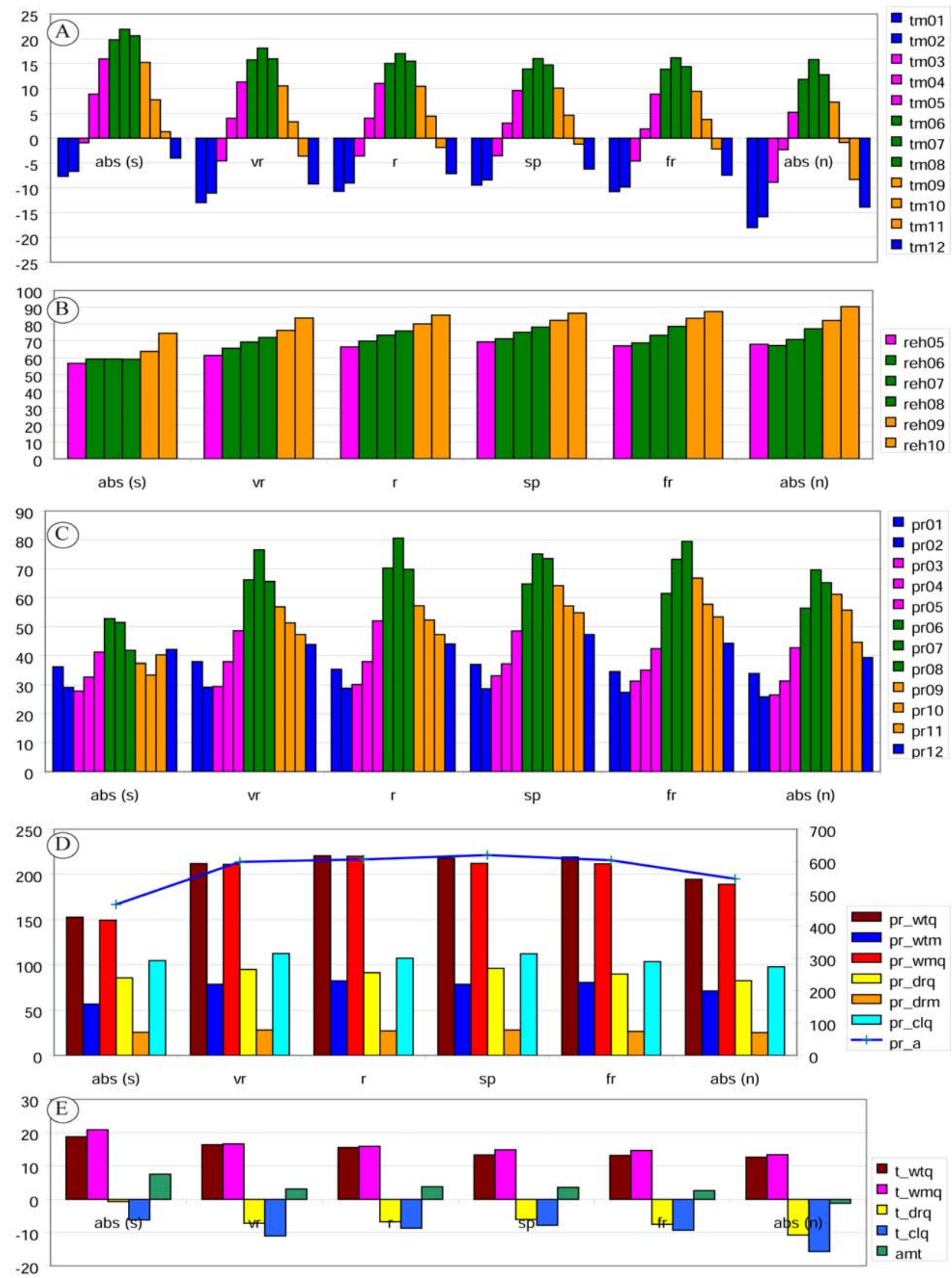

Fig. 9. Absolute values of climatic variables (see Table 1 for abbreviations) for zones of abundance (shown in Fig. 5) of Sphagnum papillosum: A - temperature, monthly; B - relative humidity, warm months only; C - precipitation, monthly; D precipitation (blue line indicates annual precipitation, with scale on the right; bars show precipitation by selected periods, their scales are on the left); E - temperature of selected periods. 

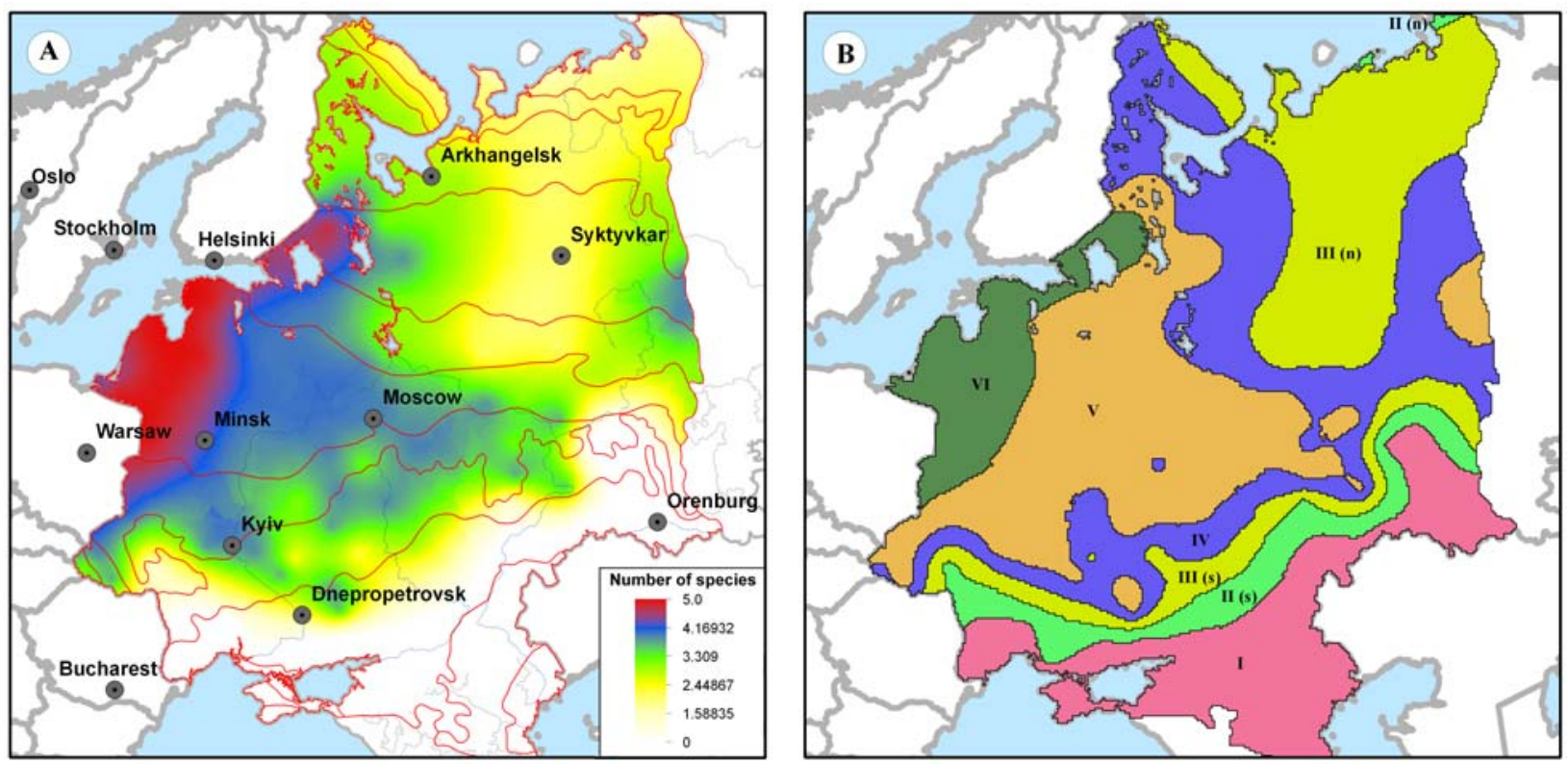

Fig. 10. Diversity of species of Sphagnum section Sphagnum in the territory of East European Plain. A - model map of species diversity; B - zones of diversity: zone I: 0 species; II: 1; III: 2; IV: 3; V: 4; and VI: 5 species; (n) Northern subzones, (s) - Southern subzones.

tors of $S$. centrale are summer temperatures, not too hot and not too cold, while the climatic optimum is determined by rainfall in autumn and summer. The requirements in humidity above $60 \%$ during the growing season and annual precipitation of $600 \mathrm{~mm}$ are apparent from Fig. 7. These conclusions are similar to those obtained by Melosik (2006) for Poland.

The regression analysis shows that the occurrence of $S$. centrale in EEP is determined by climatic factors at 95.5\% (Table 6).

\section{Sphagnum magellanicum}

Distribution maps of S. magellanicum (Figs. 4, 5) show dependence of its distribution on temperature, precipitation and air humidity (Fig. 3).

Similar to S. centrale, S. magellanicum occurs from tundra to steppe zones, increasing its abundance to the Northwestern part of European Russia. Correlation analysis reveals the same trends as were detected for $S$. centrale (Table 5). Borders between zones of its sporadic / rare abundance follow summer temperatures, both in the north and in the south.

Contrary to $S$. centrale, S. magellanicum has a higher abundance in peatlands; it dominates in raised bogs and oligotrophic mires and often reaches the maximum value of abundance, 5 in local floras. Similar to other species, its abundant presence requires no less than $60 \%$ relative humidity during all months of the vegetation period (Fig. 8C) and no less than $550 \mathrm{~mm}$ of annual precipitation (Fig. 8D).

The regression analysis shows that the occurrence of $S$. magellanicum in EEP is determined by climatic factors at $94.7 \%$ (Table 6).

\section{Sphagnum papillosum}

This species is more common in oceanic climates and in the mountains, thus the boundaries of its abundance zones cross boundaries of vegetation zones and isotherms (Fig. 4, 5D). It has maximum abundance in the Northwestern parts of EEP, where it reaches the value 4 in local floras.

Its abundance positively correlates with relative humidity of all months of the growing season, although the strongest values of this correlation are in August to October, i.e. similar to other species. Apparently, it is less sensitive to temperature than to humidity, although it certainly avoids too cold and too hot regions. Its absence between the Urals and central regions of European Russia can be explained by extremely low humidity in the first half of summer (Fig. 3G-H).

The regression analysis shows that the occurrence of S. papillosum in the EEP is determined by climatic factors at $91.8 \%$ (Table 6).

\section{Sphagnum austinii and S.affine}

These two species were recorded in Russia only after Flatberg (1984) worldwide revision of the S. imbricatumcomplex, and subsequent study of this group in Russia by Maximov (2007). Therefore, in the mapping of the distribution of these species, we primarily rely on the data of their distribution in the countries adjacent to Russia (Abolin, 1968; Ingerpuu \& Vellak, 1995; Melosik, 2006; Dite et al., 2007; Ingerpuu et al., 2014). We refer the records of Sphagnum imbricatum in Belarus (Pidoplichko, 1948; Rykovskiy \& Maslowski, 2009) and Kaliningrad Province (Napreenko, 1999) to Sphagnum austinii, based on the data on their distribution given by Maksimov (2007) and the presence of $S$. austinii in the neighboring western floras.

S. austinii and S. affine are extremely rare in EEP. This made impossible to conduct a multivariate analysis of their distribution data at a significance level of $\mathrm{p}<$ 0.05 . Therefore, the results of correlation and regression 

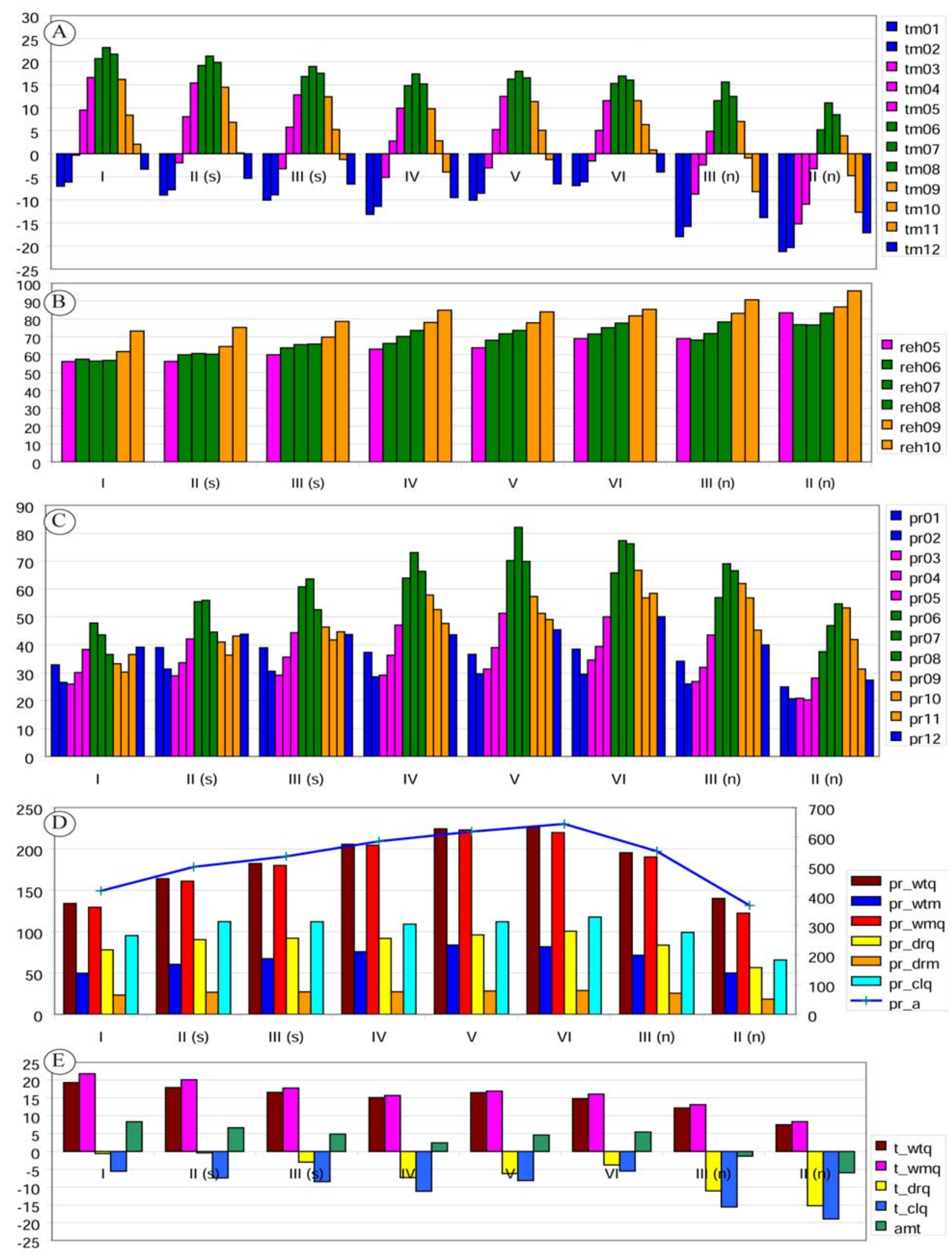

Fig. 11. Absolute values of climatic variables (see Table 1 for abbreviations) for the zones of diversity (shown in Fig. 10). Zones have the following number of species: I - 0; II - 1; III - 2; IV - 3; V - 4; VI - 5; (n) the northern subzone, (s) - southern subzone. A - temperature, monthly; B - relative humidity, warm months only; C - precipitation, monthly; D - precipitation (blue line indicates annual precipitation, with scale on the right; bars shows precipitation by selected periods, their scales are on the left); E - temperature of selected periods. 
analyses presented in Tables 5 and 6 should be considered statistically unreliable. In other words, the question of the distribution of these species on the territory of EEP requires further research.

The maps of the species distribution presented above (Figs. 4-5) are similar in showing the great abundance of species in regions closer to the Baltic Sea. This looks natural, as they have most humid climate as compared with other parts of the study area. The areas where Sphagna are common are generally outlined by the values of annual precipitation not less than $550 \mathrm{~mm}$, relative humidity not less than $60-70 \%$ and precipitation of warmest quarter of at least $150-200 \mathrm{~mm}$.

Two species, S. palustre and S. papillosum, are rather sensitive to moisture. They start to decline when the annual precipitation become less than $600 \mathrm{~mm}$ and relative humidity - lower than $70 \%$ of (Figs. 6, 9). Such high values are atypical for the area as a whole, being more common near the Baltic Sea only. Apparently, $S$. affine and especially $S$. austinii also strongly depend on the more oceanic climate, despite the unreliable data due to species rarity. However, their range in Europe (Flatberg, 1984; Ros et al., 2013) and absence in the eastern part of European Russia and Siberia (Maksimov, 2007) definitely indicate their oceanic or suboceanic ecology.

The diversity of species of the Sphagnum section Sphagnum in the territory of the East European Plain.

Maps in Fig. 10 show that the highest species diversity of section Sphagnum is in the western part of EEP, the wettest region within the study area. The leading factors found in the correlation analysis (Table 5) include the relative humidity, precipitation of the warm period and precipitation of the summer months. The pairwise analysis in Fig. 11C,D also confirms that number of species in the diversity zones depends primarily on precipitation.

In contrast to the higher abundance of individual species in wetter regions of EEP, the species diversity also increases in mountain areas, e.g., in the Urals and Carpathians, which is a common pattern in mosses in general (Ignatov, 1993). A noteworthy zone of low species diversity between the Urals and Central regions of Russia, zone $\mathbf{I I I}(\boldsymbol{n})$ is explained by the rarity of S. papillosum, which can not tolerate extensive periods of low air humidity in late spring and in the first half of summer. Nold and thus relatively dry Arctic air masses affect this area (Alisov, 1956). In addition, the route of occasional dry air masses from Kazakhstan follows along the CisUrals, contributing to overall continentality of the region (Alisov, 1956).

In the south. Sphagnum species penetrate to the steppe zone, where peat mosses occur in floodplain swamps and in Betula stands in swampy depressions (Blagoveschenskij \& Blagoveschenskaya, 1982; Boiko, 2009).

The regression analysis reaffirms that the number of species in the East European Plain is generally determined by all climatic factors (Table 1) at a high significance level (93.3\%) (Table 6).

\section{ACKNOWLEDGEMENTS}

I am very grateful to Dr. Michael Ignatov's helpful comments on the manuscript. Also I would like to express my deep gratitude to Ivan Popov for assistance with data processing.

\section{LITERATURE CITED}

ABAKAROVA, A.S., V.E. FEDOSOV, G.YA. DOROSHINA. 2015. Mosses of Tsudakhar (Dagestan, Caucasus) Arctoa 24: 536-540.

[ABOLINA, A.А.] АБОЛИНь А.А. 1968. Листостебельные мхи Латвийской CCP. - [Mosses of Latvian SSR]. Рига, Зинатне [Riga Zinatne], 329 pp.

[ABRAMOV, I.I. \& L.A. VOLKOVA] АБРАМОВ И.И., Л.А. ВОЛКОВА. 1998. Определитель листостебельных мхов Карелии. - [Handbook of mosses of Karelia] Arctoa 7, suppl. 1:390 pp.

[ABRAMOV, I.I.] АБРАМОВ И.И. 1969. Географические закономерности распространения мхов. - [Geographical distribution patterns of mosses] Ботанический журнал [Botanicheskij Zhurnal] 54 (1): 33-46.

AFONINA O.M. \& I.V. CZERNYADJEVA. 1995. Mosses of the Russian Arctic: check-list and bibliography. - Arctoa 5: 99-142.

[ALISOV, В.Р.] АЛИСОВ Б.П. 1956. Климат СССР. - [Climate of the USSR] Москва, издательство Московского университета [Mоscow, izdatel'stvo Moskovskogo universiteta], 126 pp.

[ANDREEVA, E.N, \& E.O. FILIPJEVA] АНДPEЕBA E.H., E.O. ФИЛИПЬЕВА. 2005. Мохообразные заказника "Ремдовский" (Псковская область) - [Bryophytes of «Remdovskii» Reserve] Новости систематики низших растений [Novosti sistematiki nizshikh rastenij] 38: 307-327.

ANISHCHENKO, L.N. 2007. On the bryoflora of the "Bryansky les" Reserve (Nerusso-Desnyanskoe Polessye, European Russia). - Arctoa 16: $175-180$.

[ARISKINA, N.P.] AРИСКИНА Н.П. 1978. Краткий определитель листостебельных мхов Татарской АCCP. - [A guide on the mosses of Tatarskaya ASSR] Казань, Казанский университет [Kazan, Kaznsky universitet], 122 pp.

BAISHEVA, E.Z., E.A. IGNATOVA, N. KALINAUSKAITE \& A.D. POTEMKIN. 2015. On the Bryophyte flora of Iremel National Park (Southern Urals). - Arctoa 24: 194-203.

[BELKINA, O.A. \& A.YU. LIKHACHEV] БЕЛКИНА О.А., А.Ю. ЛИХАЧЕВ. 1997. Конспект флоры листостебельных мхов Кандалакшского заповедника (Белое море). - [List of mosses of the Kandalkshsky State Reserve] Anатиты, Кольский научный центр PAH [Apatity, Kol'skii nauchnyj centr RAN] 46 pp.

[BELKINA, O.A. \& A. YU. LIKHACHEV] БЕЛКИНА О.А., А.Ю. ЛИХАЧЕВ. 2004. Флора листостебельных мхов горных массивов Чильтальд и Ионн-Ньюгоайв (Мурманская область). - [Moss flora of Chil'tald and Ionn-Njugoayv mountains (Murmansk Province, Russia)] Arctoa 13: 211-222.

[BELKINA, O.A. \& A.YU. LIKHACHEV] БЕЛКИНА О.А., А.Ю ЛИХАЧЕВ. 2010. Список листостебельных мхов Лапландского заповедника. - [Check-list of mosses of Laplandsky State Reserve] Вестник МГТУ [Vestnik MGTU] 13(4/2): 984-988.

[BEZGODOV, A.G.] БЕЗГОДОВ А.Г. 2002. К бриофлоре окрестностей Кунгура (Пермская обл.). - [On the bryoflora of the Kungur city environs (Perm Province)] Arctoa 11: 53-62.

BIOCLIM project. 2009. http://www.andra.fr/bioclim

[BLAGOVESCHENSKYI I.V. \& N.V. BLAGOVESCHENSKAYA] БЛАГОВЕЩЕНСКИЙ И.В., Н.В. БЛАГОВЕЩЕНСКАЯ. 1982. Некоторые данные о распространении сфагновых мхов Ульяновского Предволжья. - [Some data on the distribution of Sphag- 
num mosses in Ulyanovsk Predvolzhje] Ботанический журнал. [Botanicheskij Zhurnal] 67(7): 993-996.

[BOCH, M.S. \& E.O. KUZMINA] БОЧ М.С., Е.О. КУЗЬМИНА. 1985. O сфагновых мхах Северо-Запада РСФСР. - [On the Sphagnum mosses of North-West of the RSFSR] Ботанический журнал [Botanicheskij Zhurnal] 70(10): 1337-1346.

[BOGDANOVA, G.V.] БОГДАНОВА H.E. 1981. Мохообразные острова Великий (Белое море). - [Mosses of the island Velikii (White Sea)]. Москва, Флористические исследования в заповедниках CCCP [Moscow, Floristicheskie issledovaniya v zapovednikah SSSR], $112 \mathrm{pp}$.

[ВОҮCHUК, М.А.] БОЙЧУК М.А. 2001. К флоре листостебельных мхов заповедника "Костомукшский” и окрестностей города Костомукша (Карелия). - [On the moss flora of State Reserve "Kostomukshski" and the surroundings of town Kostomulsha (Karelia)] Новости систематики низиих растений [Novosti sistematiki nizshikh rastenij] 5: 217-229.

[BOICHUK, M.A., V.K. ANTIPIN, V.A. BAKALIN \& P.N. LAPSHIN] БОЙЧУК М.А., В.К. АНТИПИН, В.А. БАКАЛИН, П.Н. ЛАПШИН. 2002. Материалы к изучению бриофлоры Водлозерского национального парка. - [Contributions to study of bryoflora of Vodlozerski National Park] Новости систематики низиих растений [Novosti sistematiki nizshikh rastenij] 36: 213-224.

[BOІКO, M.F.] БОЙКО М.Ф. 2009. Мохоподібні степовоі зони Украіни. - [Bryophytes of the Ukrainian Steppe zone]. Херсон, Айлант [Kherson, Ailant], $264 \mathrm{pp}$.

[BOLJUKH, V.A.] БОЛЮХ В.А. 1995. Сравнение флоры мхов центральной части Подолии (Украина) и сопредельных регионов. - [A comparison of moss flora of Central Podolia (Ukraine) and adjacent region] Arctoa 4: 45-54.

CHEE WAI-LIN \& DALE H. VITT. 1989. The vegetation, surface water chemistry and peat chemistry of moderate-rich fens in Central Alberta. Wetlands 9(2): 227-261.

[CHERNYADJEVA I.V., N.A. KONSTANTINOVA, G.A. BOGDANOV, S.YU. POPOV \& A.N. SAVCНЕNКО] ЧЕРНЯДЬЕВА И.В., Н.А. КОНСТАНТИНОВА, Г.А. БОГДАНОВ, С.Ю. ПОПОВ. 2013. Антоцеротовые и мохообразные заповедника “Большая Кокшага. - [The Anthocerotaceae and Bryophytic in the Bolshaya Kokshaga reserve] Научные труды государственного природного заповедника “Большая Кокшага" [Nauchnye trudy gosudarstvennogo prirodnogo zapovednika "Bol'shaya Kokshaga”] 6: 91-118.

[CHERNYADJEVA, I.V.] ЧЕРНЯДЬЕВА И.В. 2001. Листостебельные мхи заповедника Большая Кокшага. - [Mosses of Bolshaya Kokshaga Reserve] Новости систематики низиих растений [Novosti sistematiki nizshikh rastenij] 35: 266-278.

[CHURAKOVA, E.Yu.] ЧУРАКОВА Е.Ю. 2002. Листостебельные мхи таежной зоны Архангельской области. [Mosses of the Taiga zone of the Arkhangelsk Province (Northern European Russia)] Arctoa 11: 351-392.

CLYMO, R.S. 1965. Experiment on breakdown of Sphagnum in two bogs. - Journal of Ecology 5: 747-757.

DANIELS, R.E. \& A. EDDY. 1990. Handbook of European Sphagna. London, HMSO. $263 \mathrm{pp}$.

[DYACHENKO, A.P., E.A. IGNATOVA \& L.V. MARINA] ДЬЯЧЕНКО А.П., Е.А. ИГНАТОВА, Л.В. МАРИНА. 1996. Мхи Висимского заповедника (Средний Урал). - [Mosses of the Visimskij State Reserve (Middle Ural Mountains)] Arctoa 6: 1-6.

[DYACHENKO, A.P. \& E.A. DYACHENKO] ДЬЯЧЕНКО А.П., Е.А. ДЬЯЧЕНКО. 2010. Мхи заповедника Денежкин камен. - [Mosses of State Reserve «Denezhkin Kamen»] Бриология: традиции и современность, Санкт-Петербург, Ammaше. [Bryology: traditions and state of art, Sankt-Peterburg, Attashe]: 59-64.

DÍTĚ, D., M. HÁJEK \& P. HÁJKOVÁ. 2007. Formal definition of Slovackian mire plant associations and their application in regional research Biologia, Bratislava 62/4: 400-408.

DOLNIK, C. \& M.G. NAPREENKO. 2007. The bryophytes of the Southern Curonian Spit (Baltic Sea coast). - Arctoa 16: 35-46.
[DOROSHINA, G.YA.] ДОРОШИНА Г.Я. 2011. Мхи Южной Калмыкии (Европейская часть России). - [Mosses of South Kalmykia] Новости систематики низших растений [Novosti sistematiki nizshikh rastenij] 45: 292-300.

[DOROSHINA-UKRAINSKAYA, G.YA.] ДОРОШИНА-УКРАИНСКАЯ Г.Я. 1999. Мохообразные. - [Bryophytes] Труды государственного заповедника «Приволжскаяя лесостепь» [Trudy gosudarstvennogo zapovednika "Privolzhskayaya lesostep"»]: 43-46.

[ELINA G.A., O.L. KUZNETSOV \& A.I. MAKSIMOV] ЕЛИНА Г.А., О.Л. КУЗНЕЦОВ, А.И. МАКСИМОВ. 1984. Структурно-функциональная организация и динамика болотных экосистем Карелии. - [Structural and functional organization and dynamics of wetland ecosystems in Karelia] Ленинград, Наука [Leningrad, Nauka], 128 pp.

ERZBERGER, P., M. HÖHN, T. POCS. 2012. Contribution to the bryoflora of Calimani Mountains in the Eastern Carpatians. - Acta Biologica Plantarum Agriensis 2: 73-95.

[FEDOSOV V.E. \& S.YU. РОРОV] ФЕДОСОВ В.Э., ПОПОВ С.Ю. 2004. Бриофлора Костромской таежной станции. - [Bryophyte flora of Kostromskaya taiga station (European Russia, Kostroma Province)] Arctoa 13: 183-195.

[FILIPPOV, D.A. \& M.A. BOICHUK] ФИЛИППОВ Д.А., М.A. БОЙЧУК. 2015. Мхи Шиченгского заказника (Вологодская область). - [Mosses of Shichengski Reserve (Vologda Province)] Вестник Северного (Арктического) федерального университета. Серия: Eстественные науки [Vestnik Severnogo (Arkticheskogo) federal'nogo universiteta. Seriya: Estestvennye nauki] 2: 80-89.

FLATBERG, K. I. 1984. A taxonomic revision of the Sphagnum imbricatum complex. - K. Norske Vidensk. Selsk. Skr. 3: 1-80.

[GAPON, S.V.] ГАПОН C.B. 1997. Конспект бріофлори лівобережного лісостепу Украіни. - [List of mosses of Ukrainian forest-steppe] Полтава, Полтавський державний педагогічний інститут им. В.Г. Короленка [Poltavs 'kij derzhavnij pedagogichnij institut im. V.G. Korolenka], $37 \mathrm{pp}$.

GIGNAC, L.D. \& D.V. VITT. 1990. Habitat limitation of Sphagnum along climatic, chemical and physical gradients in mires of Western Canada. Bryologist 93 (1): 7-22.

GIGNAC, D., D.H. VITT, S.C. ZOLTAI, S.E. BAYLEY. 1991. Bryophyte response surface along climatic, chemical and physical gradients in peatlands of Western Canada. - Nova Hedwigia 53(1-2): 27-71.

[GRABOVIK, S.I. \& V.K. ANTIPIN] ГРАБОВИК С.И., В.К. АНТИПИН. 1982. Линейный прирост и величина живой части некоторых видов сфагновых мхов и их связь с гидрометеорологическими показателями. - [Linear growth and the value of the living part of some species of sphagnum moss and their relation to hydro-meteorological parameters]. Эколого-биологические особенности и продуктивность растений болот. Петрозаводск [Ekologo-biologicheskie osobennosti i produktivnost' rastenij bolot. Petrozavodsk]: 195-203.

[GRABOVIK, S.I. \& V.K. ANTIPIN] ГРАБОВИК С.И., В.К. АНТИПИН. 2015. Тренды многолетней динамики годичного прироста сфагновых мхов в Карелии. - [Trends in long-term dynamics of the annual growth of sphagnum mosses in Karelia]. Материаль международной бриологической конференции, посвященной 100 летию со дня рождения Анастасии Лаврентьевны Абрамовой,Санкт-Петербург, СПбГЭТУ «ЛЭТИ» [Materialy mezhdunarodnoj briologicheskoj konferencii, posvyashchennoj 100letiyu so dnya rozhdeniya Anastasii Lavrent'evny Abramovoj,SanktPeterburg, SPbGEHTU “LEHTI”']: 47-50.

[GRABOVIK, S.I.] ГРАБОВИК С.И. 1994. Влияние климатических условий на линейный прирост сфагновых мхов в Карелии. - [Effect of climatic conditions on the linear growth of sphagnum mosses in Karelia] Ботанический журнал [Botanicheskij Zhurnal] 79(4): 81-86.

HIJMANS, R.J., S.E. CAMERON, J.L. PARRA, P.G. JONES \& A. JARVIS. 2005. Very high resolution interpolated climate surfaces for global land areas. - International Journal of Climatology 25: 1965-1978.

IGNATOV, M.S. 1993. Moss diversity patterns on the territory of the former USSR. - Arctoa 2: 13-47. 
[IGNATOV, M.S. \& E.A. IGNATOVA] ИГНАТОВ М.C., Е.А. ИГНАTOBA. 1994. Материалы к познанию бриофлоры Московской области. - [Matters to the knowledge of bryoflora of the Moscow Province] Флористические исследования в Московской области, Москва, Наука [Floristicheskie issledovaniya v Moskovskoj oblast,. Moscow, Nauka]: 121-179.

[IGNATOV, M.S. \& E.A. IGNATOVA] ИГНАТОВ М.С., Е.А. ИГНАTOВА. 2003. Флора мхов средней части Европейской России. Т.1. - [Moss flora of Middle Part of European Russia, V.1] Москва, КМК [Moscow, KMK], $608 \mathrm{pp}$.

IGNATOV, M.S., E.A. IGNATOVA \& N.A. KONSTANTINOVA. 2005 Bryophyte flora of the Volzhsko-Kamskiy Nature Reserve (Tatarstan, European Russia). - Arctoa 14: 49-66.

IGNATOV, M.S., E.A. IGNATOVA, E.N. KURAEVA, T.YU. MINAEVA \& A.D. POTEMKIN. 1998. Bryophyte flora of Zentral'no-Lesnoj Biosphere Nature Reserve (European Russia, Tver Province). - Arctoa 7 : $45-58$.

[IGNATOV, M.S., E.A. IGNATOVA, V.E. FEDOSOV \& N.A. KONSTANTINOVA] ИГНАТОВ М.C., Е.А. ИГНАТОВА, В.Э. ФЕДОСОВ, Н.А. КОНСТАНТИНОВА. 2001. Краткий определитель мохообразных Подмосковья. - [Bryophytes of Moscow Province: a guide] M., KMK [Moscow, KMK], $320 \mathrm{pp}$.

[IGNATOV, M.S., E.A. IGNATOVA, S.YU. POPOV, E.YU. CHURAKOVA, T.YU. BRASLAVSKAYA \& I.B. KUCHEROV] ИГНАТОВ М.С., Е.А. ИГНАТОВА, С.Ю. ПОПОВ, Е.Ю. ЧУРАКОВА, Т.Ю. БРАСЛАВСКАЯ, И.Б. КУЧЕРОВ. 2008. Листостебельные мхи. [Mosses] Компоненты экосистем и биоразнообразие карстовых территорий Европейского Севера России, Архангельск, ГПЗ "Пинежский" [Ecosystem components and biodiversity of karst areas in European North of Russia, Arkhangelsk, Pinega State Reserve]: 177-197.

IGNATOVA, E.A., M.S. IGNATOV \& A.G. BEZGODOV. 1995. Moss flora of the Basegi State Reserve (Perm Province, Middle Ural Mountains). - Arctoa 4: 23-34.

[IGNATOVA, E.A., M.S. IGNATOV \& A.G. BEZGODOV] ИГНАTOBA Е.А., М.С. ИГНАТОВ, А.Г. БЕЗГОДОВ. 1996. Мхи Вишерского заповедника (Пермская область, Северный Урал). - [Mosses of the Vishera State Reserve (Perm Province, Northern Ural Mountains)] Arctoa 6: 7-19

IGNATOVA, E.A., M.S. IGNATOV, A.P. SEREGIN, T.V. AKATOVA \& N.A. KONSTANTINOVA. 2005. Bryophyte flora of the projected Utrish Reserve (North-West Caucasus, Russia). - Arctoa 14: 39-48.

INGERPUU, N. \& K. VELLAK. 1996. The distribution and some ecological characteristics of Estonian rare bryophytes. - Arctoa 5: 143-148

[KARMAZINA, E.V.] KAPMAЗИНА Е.В. 2013. Эколого-ценотическая характеристика мохообразных национального парка "Русский Север". - [Ecologo-phytocenotic characteristics of mosses of the National Park "Russkii Sever"] Дисс. канд. биол. Наук. М., МГУ им. M.В.Ломоносова [Ph.D., Moscow, Lomonosov State University], 244 pp.

[KUDRYASHOV, L.V.] КУДРЯшOВ Л.В. 1940. Некоторые закономерности в распределении сфагновых мхов в Европейской части CCCP. - [Some regularities in the distribution of sphagnum moss in the European part of the USSR]. Труды ботанического сада МГУ [Trudy botanicheskogo sada MGU] 3: 120-162.

[KUDRYASHOV, L.V.] КУДРЯШОВ Л.В. 1945. Географическое распространение рода Sphagnum в Европейской части CCCP. - [The geographical distribution of the genus Sphagnum in the European part of the USSR] Учёные записки Московского университета [Uchyonye zapiski Moskovskogo universiteta] 82: 96-102.

[KURNAEV, S.F.] КУРНAEB С.Ф. 1973. Лесорастительное районирование CCCP. - [Forest growth zoning of the USSR] M., Наука [Mоscow, Nauka], 203 pp.

[LIKHACHEV, A.YU. \& O.A. BELKINA]. ЛИХАЧЕВ А.Ю., О.А. БЕЛКИНА. 1999. Листостебельные мхи горного массива Лавна-тундра (Мурманская область, Россия). - [Mosses of Lavna-Tundra Mountains (Murmansk Province, Russia)] Arctoa 8: 5-16.
LUKEN, J.O. 1985. Zonation of Sphagnum Mosses: Interactions among shoot growth, growth form, and water balance. - Bryologist 88(4): 374379 .

LAINE, J, P. HARJU, T. TIMONEN, A. LAINE, E.-S. TUITTILA, K MINKKINEN \& H. VASANDER. 2009. The intricate beauty of Sphagnum mosses: a Finnish guide for identification. - University of Helsinki, Department of Forest Ecology Publications 39: 1-190 pp.

[LUR'E, I.K.] ЛУРЬЕ И.К. 2010. Геоинформационное картографирование. - [Geoinformatical mapping] Методы геоинформатики и цифровой обработки космических снимков. М., КДУ. - [Metody geoinformatiki i cifrovoj obrabotki kosmicheskih snimkov], 424 pp.

[MAKSIMOV, A.I.] МАКСИМОВ А.И. 1982. К вопросу о приросте сфагновых мхов. - [To a matter about the growth of sphagnum mosses] Комплексные исследования растительности болот Карелии. Петрозаводск [Kompleksnye issledovaniya rastitel'nosti bolot Karelii]: $170-178$

MAKSIMOV, A.I. 2007. Sphagnum imbricatum complex (Sphagnaceae, Bryophyta) in Russia. - Arctoa 16: 25-34.

[MAKSIMOV, A.I. \& O.V. KUZNETSOV] МАКСИМOB А.И., О.В. КУЗНЕЦОВ. 2009. Флора мхов планируемого национального прака "Тулос" (Республика Карелия). - [Moss flora of the planned national park "Tuulos" (Republik of Karelia)] Новости систематики низших растений [Novosti sistematiki nizshikh rastenij] 43: 362-376.

MAZING V., YU.M. SVIREZHEV, H. LOFFLER \& B.C. PATTEN. 1990. Wetlands in the biosphere. - Wetlands and Shallow Continental Water Bodies 1: 313-344.

MELOSIK, I. 2006. Species of the type section of Sphagnum (Bryophyta, Sphagnaceae) in Poland. - Biodiversity: reasearch and conservation 1-2: 69-76.

[NAPREENKO, M.G. \& L.V. RAZGULYAEVA] НАПРЕEНКО М.Г., Л.В. РАЗГУЛЯЕВА. 1999. Сфагновые мхи Калининградской области. - [Sphagna of Kaliningrad Province (European Russia)] Arctoa 8: $27-34$.

[NOTOV, A.A., U.N. SPIRINA, E.A. IGNATOVA \& M.S. IGNATOV] НОТОВ А.А., У.Н, СПИРИНА, Е.А. ИГНАТОВА, М.С. ИГНАТОВ. 2002. Листостебельные мхи Тверской области (Средняя полоса Европейской России). - [Mosses of the Tver Province (Middle Part of European Russia)] Arctoa 11: 297-332.

PAPP, B., P. ERZBERGER, P. ODOR, ZS. HOCK, P. SZOVEYI, E. SZURDOKI \& Z. TOTH. 2010. Updated checklist and red list of Hungarian Bryophytes. - Studia botanica hungarica 41: 31-59.

[PARTYKA, L.YA.] ПАРТЫКА Л.Я. 2005. Бриофлора Крыма. [Bryoflora of Crimea] Киев, Фитосоииоиентр [Kiev, Fitosociocentr], $170 \mathrm{pp}$.

[PIDOPLICHKO, A.P.] ПИДОПЛИЧКО А.П. 1948. Флора сфагновых (торфяных) мхов Белорусской CCP. - [Flora of Sphagnum (peat) mosses of Belorussian SSR] Минск, АН БССР [Minsk, AN BSSR], 70 pp.

[POPOV, S.YU.] ПОПОВ С.Ю. 2000. Флора сфагновых мхов Жигулёвского заповедника. - [Flora of peat mosses of the Zhigulevskij State Reserve] Биологическое разнообразие заповедных территорий: оценка, охрана, мониторинг, M.-Самара [Biologicheskoe raznoobrazie zapovednyh territorij: ocenka, ohrana, monitoring, Moscow-Samara]: 194-196.

POPOV, S.YU. 2012. On the morphological plasticity of Sphagnum mosses - International Bryological conference dedicated to 100 year anniversary of R.N. Schljakov, Apatity: 59-61.

[POPOV, S.YU.] ПОПОВ С.Ю. 2013. Геоинформационные системы и пространственный анализ данных в науках о лесе. - [Geographic information systems and spatial data analysis in the sciences of forest]. Санкт-Петербург, "Интермедия" [Sankt-Peterburg, Intermedia], $400 \mathrm{pp}$.

[POPOV, S.YU. \& N.N. BURYANINA] ПОПОВ C.Ю., Н.Н. БУРЯНИНА. 2012. Особенности экологии сфагновых мхов в северной тайге.- [Features of ecology of sphagnum moss in the northern taiga]. Многолетняя динамика компонентов экосистем природного комплекса Пинезсккого заповедника и сопредельных территорий Архан- 
гельск, ГПЗ “Пинежский” [Mnogoletnyaya dinamika komponentov ehkosistem prirodnogo kompleksa Pinezhskogo zapovednika $i$ sopredel'nyh territorij. Arhangel'sk, GPZ “Pinezhskij”']: 51-63.

[POPOV, S.YU., S.A. MOSHKOVSKI, K.I. BELOVEZHEC, T.S. CHUPALENKOVA, N.L. MEL'NICHENKO \& M.S. IGNATOV] ПОПОВ С.Ю., С.А. МОШКОВСКИЙ, К.И. БЕЛОВЕЖЕЦ, Т.С. ЧУПАЛЕНКОВА, Н.Л. МЕЛЬНИЧЕНКО, М.С. ИГНАТОВ. 2001. Материалы по бриологической экспедиции по государственному природному заповеднику “Присурский”. - [The results of bryological expedition to the state nature reserve "Prisursky"]. Экологическии вестник Чуватской республики [Ekologicheskij vestnik Chuvashskoj respubliki] 25: 29-34.

[POPOV, S.YU., V.E. FEDOSOV, S.A. MOSHKOVSKY \& M.S IGNATOV] ПОПОВ С.Ю., В.Э. ФЕДОСОВ, С.А. МОШКОВСКИЙ, М.С. ИГНАТОВ. 2004. Флора мхов Керженского заповедника (Нижегородская область, Европейская часть России). - [Moss flora of Kerzhensky State Reserve (Nizhniy Novgorod Province, European Russia)] Arctoa 13: 57-66.

[POPOVA, N.N.] ПОПОВА Н.H. 1999. Мохообразные. - [Bryophytes] Флора и фауна заповедников, M. [Flora I fauna zapovednikov, Moscow]: 96-111.

[POPOVA, N.N.] ПОПОВА Н.Н. 2002. Бриофлора Среднерусской возвышенности. I. - [Bryoflora of the Central Russian Uppland. I] Arctoa 11: 101-168

[POPOVA, N.N.] ПОПОВА Н.Н. 1999. Мохообразные (Bryophyta) Липецкой области. - [Mosses (Bryophyta) of the Lipetsk Province] Ботанический журнал [Botanicheskij Zhurnal] 84(4): 72-78.

ROS, R.M., V. MAZIMPAKA, U. ABOU-SALAMA, M. ALEF-FI, T.L. BLOCKEEL, M. BRUGUÉS, R.M. CROS, M.G. DIA, G.M. DIRKSE, I. DRAPER, W. EL-SAADAWI, A. ERDAG, A. GANE-VA, R. GABRIEL, J.M. GONZÁLEZ-MANCEBO, C. GRANGER, I. HERRNSTADT, V. HUGONNOT, K. KHALIL, H. KÜRSCHNER,A. LOSADA-LIMA, L. LUÍS, S.D. MIFSUD, M. PRIVITERA, M.PUGLISI, M.S. SABOVLJEVIC, C. SÉRGIO, H.M. SHABBARA M. SIM-SIM, A. SOTIAUX, R. TACCHI, A. VANDERPOORTEN \& O. WERNER. 2013. Mosses of the Mediterranean, an annotated checklist. - Cryptogamie Bryolgie 34(2): 99-283.

[RUBTSOVA, A.V.] РУБЦОВА А.В. 2005. Бриофлора Удмуртской республики. - [Bryophyte flora of Udmurt Republic] Aктуальные проблемы бриологии, Санкт-Петербург, НЦ РАН [Aktual'nye problemy briologii. Sankt-Peterburg, NC RAN]: 171-177.

[RYKOVSKI, G.F. \& O.M. MASLOVSKI] РЫКОВСКИЙ Г.Ф., O.M. МАСЛОВСКИЙ. 2009. Флора Беларуси. Мохообразные. Т. 2. Hepaticopsida-Sphagnopsida. - [Flora of Belarus. Bryophyta. Vol. 2. Hepaticopsida-Sphagnopsida] Минск: Беларуская наука [Minsk, Belaruskaya nauka], 239 pp

[SAVICH-LJUBITSKAYA, L.I.] САВИЧ-ЛЮБИЦКАЯ Л.И. 1952. Флора споровых растений СССР. Т.1. Листостебельные мхи (1). Сфагновые (торфяные) мхи. - [Flora of spore plants of the USSR. Vol. 1. Mosses (1). Peat mosses] Москва-Ленинград, АН СССР [Moscow-Leningrad, AN SSSR], $254 \mathrm{pp}$.

[SEREBRYAKOVA, N.N.] СЕРЕБРЯКОВА Н.Н. 2009. Эколого-биологические особенности листостебельных мхов и использование их в экологическом мониторинге. - Дисс... канд.биол.наук, Capamoв [Ph.D. thesis, Saratov], 128 p.

SEREDA V.A. \& M.S. IGNATOV. 2008. Bryoflora of Nothern Azov area (Rostov-On-Don Province, European Russia). - Arctoa 17: 185-190

[SHLJAKOV, R.N. \& N.A. KONSTANTINOVA] ШЛЯКОВ P.H., Н.A. КОНСТАНТИНОВА. 1982. Конспект флоры мохообразных Мурманской области. - [List of mosses of Murmansk Province] Anaтиты, Кольский филиал AH CСCP [Apatity, Kol'skij filial AN SSSR], $227 \mathrm{pp}$

[SHMIDT, V.M.] ШМИДТ B.M. 1984. Математические методы в ботанике. - [Mathematical methods in botany] Ленинград, издательство Ленинградского университета [Leningrad, Izdatel'stvo Leningradskogo universiteta], $288 \mathrm{pp}$.
[SHUBINA, T.P. \& G.V. ZHELEZNOVA] ШУБИНА Т.П., Г.В. ЖЕЛЕЗНОВА. 1995. К флоре листостебельных мхов Мезенско-Вычегодской равнины (Республика Коми). - [On the moss flora of the Mezensko-Vychegodskaya Plain (Komi Republic)] Arctoa 5: 39-44.

[SIMONOV, G.P.] СИМОНОВ Г.П. 1978. Определитель листостебельных мхов Молдавской ССР. - [Handbook of mosses of Moldavian SSR] Кишинев, Штиинияа [Kishinev, Shtiintsa], 168 pp.

[SMOLJANITSKY, L.YA.] СМОЛЯНИЦКИЙ Л.Я. 1977. Некоторые закономерности формирования дернин сфагновых мхов. - [Some regularietes of forming Sphagnum ecads] Ботанический журнал[Botanicheskij Zhurnal] 52(9): 1269-1272.

SÖDERSTRÖM, L. (ED.) 1998. Preliminary distribution maps of bryophytes in Northwestern Europe. Vol. 3 (Musci J-Z). - Mossornas Vännar, Trondheim, $72 \mathrm{pp}$

[SPIRINA, U.N. \& V.I. ZOLOTOV] СПИРИНА У.Н., В.И. ЗОЛОТОВ. 2004. Мхи Оренбургского государственного природного заповедника (юго-восток Европейской части России). - [Mosses of the Orenburg State Nature Reserve (South-Eastern European Russia)] Arctoa 13: $51-56$

STEBEL, A. 2012. Preliminary studies on the bryoflora of Narwianski National Park (NE Poland). - Kaz. Slez. Muz. Opava (A) 61: 265-271.

[SURAGINA, S.A.] СУРАГИНА C.A. 2001. Листостебельные мхи Волгоградской области (Юго-Восток Европейской России). [Mosses of the Volgograd Province (South-Eastern European Rrussia)] Arctoa 10: 45-70.

[SURAGINA, S.A., E.A. IGNATOVA \& M.S. IGNATOV] СУРАГИНА C.A., Е.А. ИГНАТОВА, М.С. ИГНАТОВ. 2002. Материалы к флоре мхов Астраханской области (юг Европейской России). - [Contribution to the moss flora of Astrakhan Province (South European Russia)] Arctoa 11: 169-174.

TELEGANOVA, V.V. 2008. Mosses of Kaluga (Middle European Russia) and their reproductive features. - Arctoa 17: 169-184.

VELLAK K., N. INGERPUU \& E. KAROFELD. 2013. The Sphagnum mosses of Estonia. - Tartu, University of Tartu Press. 136 pp.

VITT, D.H., H. CRUM \& J.A. SNIDER. 1975. The vertical zonation of Sphagnum species in hummock-hollow complexes in Nothern Michigan. - Michigan Botanist 14: 190-200.

[VOLKOVA, E.M.] ВОЛКОВА Е.M. 2006. О распространении сфагновых мхов (Bryophyta: Sphagnaceae) в Тульской области. - [On the propagation of Sphagnum mosses (Bryophyta: Sphagnaceae) in the Tula Province]. Природа Тульской области. Bып. 1, Тула [Nature of the Tula Province. Vol. 1, Tula]: 10-15.

[VOLKOVA, L.A., A.L. ZHUKOVA, A.D. POTEMKIN \& N.D. NEMTSEVA] ВОЛКОВА Л.А., А.Л. ЖУКОВА, А.Д. ПОТЕМКИН, Н.Д. НЕМЦЕВА. 1994. Мохообразные Дарвинского государственного заповедника. - [Mosses of Darvinski State Reserve]. Флора и растительность Тверской области, Тверь, Тверской государственный университет [Flora i rastitel'nost' Tverskoj oblasti, Tver', Tverskoj gosudarstvennyj universitet]: 13-24.

[VOLOSNOVA, L.F., Е.A. IGNATOVA \& M.S. IGNATOV] ВОЛОСНОВА Л.Ф., Е.А. ИГНАТОВА, М.С. ИГНАТОВ. 2000. Бриофлора Окского заповедника (Европейская Россия, Рязанская область). [Bryophyte flora of Oksky Nature Reserve (European Russia, Ryazan province)] Arctoa 9: 3-11.

WOJTUŃ, B., A. SENDYK \& D. MARTYNIAK. 2013. Sphagnum species along environmental gradients in mires of the Sudety Mountains (SW Poland). - Boreal environment research 18: 74-88.

[YURTSEV, B.A.] ЮРЦЕВ Б.А. 1975. Некоторые тенденции развития метода конкретных флор. - [Some trends in the development of the method of specific floras] Ботанический журнал [Botanicheskij Zhurnal] 60(1): 69-83

[YURTSEV, В.А.] ЮРЦЕВ Б.А. 1982. Флора как природная система. - [Flora as a natural system]. Бюл. МОИП. Отдел биологический [Byulleten' MOIP, Otdel biologicheskij] 87(4): 3-22.

[ZEROV, D.K.] ЗЕРОВ Д.К. 1964. Флора печіночних і сфагнових мохів Украіни. - [Flora of Liverworts and Peat mosses of Ukraine] Kieв, 
Наукова Думка [Kiev, Naukova Dumka], 356 pp.

[ZEROV, D.K. \& L.YA. PARTYKA] ЗЕРОВ Д.К., Л.Я. ПАРТИКА 1975. Мохоподібні Украінских Карпат. - [Ukrainian Carpathians Bryophythes] Киів: Наукова думка [Kyiv, Naukova Dumka], 230 pp.

[ZHELEZNOVA, G.V.] ЖЕЛЕЗНОВА Г.В. 1994. Флора листостебельных мхов Европейского Северо-Востока. - [Moss flora of European NorthEast] Санкт-Петербург, Наука [Sankt-Peterburg, Nauka]: 149 pp.

[ZHELEZNOVA, G.V.] ЖЕЛЕЗНОВА Г.В. 2014. К флоре листостебельных мхов Кировской области. - [On the moss flora of the Kirov Province] Arctoa 23: 212-218.

[ZHELEZNOVA, G.V. \& T.P. SHUBINA] ЖЕЛЕЗНOBA Г.В., Т.П. ШУБИНА. 1997. Бриофлора Печоро-Илычского биосферного заповедника. - [Bryophyte flora of the Pechoro-Ilychsky State Reserve]. Флора и растительность Печоро-Ильчского биосферного заповедника, Екатеринбург, УрО РAH [Flora i rastitelnost' PecheroIlychskogo zapovednika, Ekaterinburg, URO RAN]: 175-210.

ZHELEZNOVA, G.V. \& T.P. SHUBINA. 2015. Mosses of the Belaya River Basin (Nothern Timan, Nenets Autonomous District). - Arctoa 24: 204 209 .

[ZOLOTOV, V.I. \& E.Z. BAISHEVA] ЗОЛОТОВ В.И., Э.З. БАИШЕВА 2003. Флора листостебельных мхов заповедника "Шульган-Таш" (Республика Башкортостан, Россия). - [Moss flora of “Shulgan-Tash” Nature Reserve (Republic Bashkortostan, Russia)] Arctoa 12: 121-132 